$(200)$

R290

mo. $74-240$

\title{
USGS-OFR. $74-240$
}

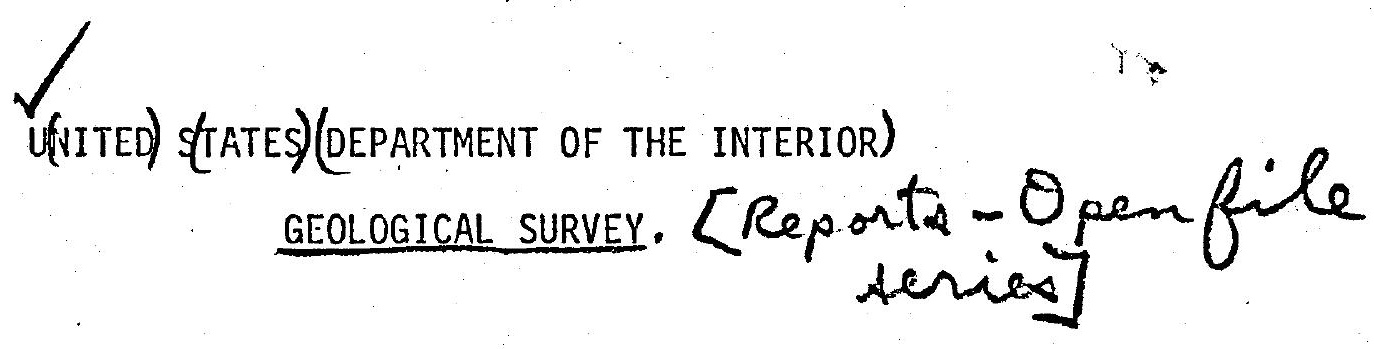

- Report on Direct Current Soundings Over a Geothermal Prospect in the Bruneau-Grand View A rea, Idaho



$$
\text { Bruneau-Grand View A rea, Idaho }
$$

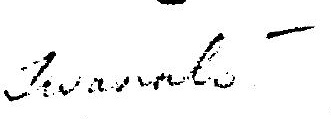

\section{PORTIONS OF THTS RRPORI}

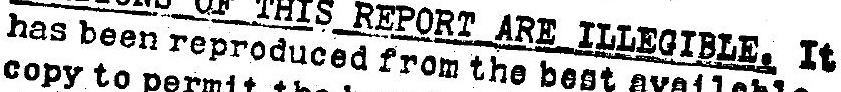
ability.

possible ava11-

By

Dailas B. Jackson $1933-$

Open-file report $74-240$

1974

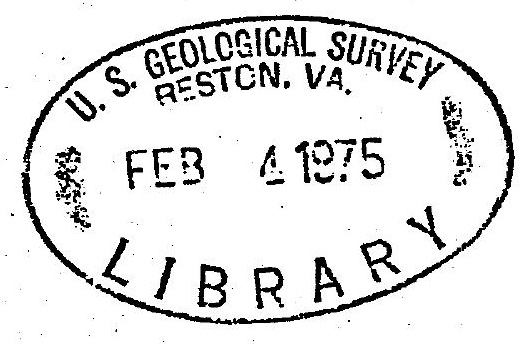

This report is preliminary and has not been edited or reviewed for conformity with U.S. Geological Survey standards and nomenclature.

\section{4}




\section{DISCLAIMER}

This report was prepared as an account of work sponsored by an agency of the United States Government. Neither the United States Government nor any agency Thereof, nor any of their employees, makes any warranty, express or implied, or assumes any legal liability or responsibility for the accuracy, completeness, or usefulness of any information, apparatus, product, or process disclosed, or represents that its use would not infringe privately owned rights. Reference herein to any specific commercial product, process, or service by trade name, trademark, manufacturer, or otherwise does not necessarily constitute or imply its endorsement, recommendation, or favoring by the United States Government or any agency thereof. The views and opinions of authors expressed herein do not necessarily state or reflect those of the United States Government or any agency thereof. 


\section{DISCLAIMER}

Portions of this document may be illegible in electronic image products. Images are produced from the best available original document. 
Geophysical technique and interpretation $\ldots \ldots \ldots \ldots \ldots \ldots \ldots \ldots$

Sounding interpretations $\ldots \ldots \ldots \ldots \ldots \ldots \ldots \ldots \ldots \ldots \ldots \ldots \ldots \ldots$

Conclusions $\ldots \ldots \ldots \ldots \ldots \ldots \ldots \ldots \ldots \ldots \ldots \ldots \ldots \ldots \ldots \ldots \ldots \ldots \ldots$

References $\ldots \ldots \ldots \ldots \ldots \ldots \ldots \ldots \ldots \ldots \ldots \ldots \ldots \ldots \ldots \ldots \ldots \ldots \ldots \ldots \ldots$ 


\section{Illustrations}

\section{[Plates are in pocket $\rfloor$}

Plate 1.--Index map of the Bruneau-Grand View area, Idaho, showing location of wells, soundings, geoelectric profiles $\underline{A}-\underline{A}^{\prime}$ and $\underline{B}_{-} \underline{B}^{\prime}$, and AMT contours.

2.--VES profiles $\underline{A}-\underline{A}^{\prime}$ and $\underline{B}-\underline{B}^{\prime}$, Bruneau-Grand View area, Idaho Page

Figure 1.--Example of Schlumberger sounding data (for VES 15) showing a layered resistivity model and a computed theoretical apparent resistivity curve for the model.. 12

Figures $2-31 .--$ Schlumberger sounding curves VES $1-30 \ldots \ldots \ldots \ldots 13$ Figure 32.--VES 31 Schlumberger sounding curve showing layered resistivity model and theoretical apparent resistivity curve for the model 


\begin{abstract}
Report on Direct Current Soundings Over a
Geothermal Prospect in the Bruneau-Grand View Area, Idaho
\end{abstract}

by Dallas B. Jackson

The U.S. Geological Survey has completed two electrical resistivity studies in the southwest part of Idaho, between the towns of Oreana and . Hammett (p1. 1). The purpose of these studies was to investigate an area identified as a potential geothermal area by Young and Mitchell (1973). The first survey, an audio-magnetotelluric (AMT) survey, completed in the early summer of 1973 (D. B. Hoover, written commun., 1974), defined a conductivity anomaly extending from near the town of Oreana on the west to within about $10 \mathrm{~km}$ of Hammett on the east. The conductive region, as outlined by the AMT survey for apparent resistivities measured at $8 \mathrm{~Hz}$, is shown on plate 1. I have chosen to discuss the $8-\mathrm{Hz}$ AMT map because $8 \mathrm{~Hz}$ was the lowest frequency recorded and thus represents the greatest depth of penetration measured in the AMT survey. The $8-\mathrm{Hz}$ contours clearly show a major low-resistivity area at the west end of the map area, bounded by steep gradients to the west, south, and northeast, but extending to the east in a trough-like shape for at least $65 \mathrm{~km}$. The major departure from this general trend is a sublateral extention of the conductive zone into the Bruneau Valley, which is interpreted by Hoover as a narrow fracture zone along which hot waters are rising.

This paper describes the results of the second electrical survey, made during September 1973; this survey consisted of $31 \mathrm{~d}-\mathrm{c}$ soundings 
used to verify the AMT anomalies and to define the vertical extent of the conductive body. The soundings were arranged along 2 profiles:

1) a profile approximately east-west along the axis of the AMT anomaly, crossing the steep AMT resistivity gradient at the west end and extending about $85 \mathrm{~km}$, to beyond the end of the AMT anomaly to the east; the exposed rocks along this profile are primarily alluvial and lake deposits of middle to late Pleistocene age, although some basalt flows of middle Pleistocene age were also traversed along the east-central part of the profile north of Bruneau (Malde and others, 1963, Young and Mitchell, $1973)$; 2) a profile south-southeast from the center of the closed $5 \mathrm{ohm}-\mathrm{m}$ AMT contour to the steep resistivity gradient $17 \mathrm{~km}$ to the south; the exposed rocks beneath this profile range from lower Pleistocene alluvial and lake deposits at the north end to basalt flows and silicic volcanic rocks of Pliocene age at the south end. In addition to the soundings along the profiles, two soundings were made north of the AMT. anomaly about halfway between Bruneau and Mounta in Home.

Geophysical technique and interpretation

All the vertical electrical soundings were made with the Schlumberger array using direct current (Keller and Frischknecht, 1966). The apparent resistivities, $\bar{\rho}_{s}$, were calculated from the equation:

$$
\bar{\rho}_{\mathrm{s}}=\frac{(\overline{\mathrm{AB}} / 2)^{2}-(\overline{\mathrm{MN}} / 2)^{2}}{\overline{M N}} \cdot \frac{\Delta V_{m n}}{I}
$$

where $\overline{A B}$ and $\overline{M N}$ are the current and potential electrode spacings, $V_{m n}$ is the potential difference between the $M$ and $N$ electrodes, and $I$ is the input current. $\bar{\rho}_{s}$ then is expressed in ohm- $\mathrm{m}^{2} / \mathrm{m}$ or more commonly, 
simply as ohm-m. By convention, the results are plotted on bilogarithmic paper with apparent resistivity plotted in the $Y$ direction and the spacing $\overline{\mathrm{AB}} / 2$ plotted in either feet or metres in the $X$ direction.

All the VES curves except 1 and 30 , which were badly distorted, were interpreted after smoothing of lateral effects and correcting for bad jumps (Kunetz, 1966) using an automatic interpretation program developed by A. A. R. Zohdy (written commun., 1974). The detailed solutions from the automatic interpretation program were simplified by smoothing of Dar Zarrouk curves calculated for the detailed layering, to provide better correlation between adjacent soundings (Zohdy, 1974a). Theoretical curves were then computed for the assumed layer thickness and resistivities (Zohdy, 1974b) and compared to the field curves. An example of field data, the computed theoretical curve; and the layered resistivity model plotted at the bottom of the graph paper for VES 15 are shown in figure 1.

Sounding interpretations

Thirty-one soundings were completed in the Bruneau-Grand View area with $\overline{\mathrm{AB}} / 2$ spacings ranging from 900 to $3700 \mathrm{~m}$. The field curves for these soundings, neither smoothed nor adjusted for jumps or lateral effects, are shown in figures 2-32. A11 of the sounding interpretations except for VES 1,30 , and 31 are shown on profiles $\underline{A}-\underline{A}^{\prime}$ and $\underline{B}-\underline{B}^{\prime}$ (p1. 2).

Layer resistivities calculated from the sounding curves have been grouped into five semilogarithmic ranges to simplify the correlation of electrical layers from sounding to sounding. Where two clearly defined layers fal1 within a resistivity range, such as at VES 11 (profile $\underline{A}-\underline{A}^{\prime}$ ), 
both layer resistivities are noted, 3.2 and $6.5 \mathrm{ohm}-\mathrm{m}$, and the layer boundary is marked by a dashed line. In addition, where layers from adjacent soundings appear to correlate, but one of the layers has a resistivity that places it just within a higher or lower resistivity range, such as the fourth layer from the surface at VES 6 (profile A- $_{-}{ }^{\prime}$ ), the layer resistivity is noted by parentheses, for example $(17.4)$, and the resistivity-range pattern for the layer from the adjacent sounding (the 18-36 ohm-m range from the 21 ohm-m beneath VES 22) is carried through.

Profile $\underline{A}-\underline{A}^{\prime}$, which lies along the axis of the AMT low, is underlain at the surface for most of its length by alluvial and lacustrine deposits of Quaternary age. The rapid lateral variations of these sedimentary layers in the upper 300 to $600 \mathrm{~m}$ are clearly shown by the poor correlation of electrical units from sounding to sounding. Resistivity variations within this part of the section are compatible with resistivities that have been observed in other areas for similar lithologies, ranging from as much as several hundred ohm-m for dry or well-washed gravels to less than $10 \mathrm{ohm}-\mathrm{m}$ for clay or clay-rich sands (Zohdy and others, 1969; Keller and Frischknecht, 1966).

of more interest than the near-surface electrical units is the conductive unit, which ranges in resistivity from $2.8 \mathrm{ohm}-\mathrm{m}$ beneath VES 23 to $7 \mathrm{ohm}-\mathrm{m}$ beneath VES 8 , and varies in thickness from about $360 \mathrm{~m}$ beneath soundings 8,22 , and 25 to about $900 \mathrm{~m}$ beneath soundings 10 , 15, and 24. Presumably, this is the unit which causes the resistivity low on the 8-Hz AMT map. Six wells along profile $\underline{A}-\underline{A}^{\prime}$ penetrate the 
conductive 1-7 ohm-m unit and each well extends through the sediments of the Idaho Group at least into the Banbury Basalt; all but 2 of the wells (well 13adal and well 16bbbl) bottom in Idavada silicic volcanics. No electrical contrasts exist between the Idaho Group and Banbury Basalt or between the Banbury Basalt and Idavada Volcanics.

Although fresh basalts near the surface usually have resistivities of the order of $100 \mathrm{ohm}-\mathrm{m}$ or greater; their resistivity decreases with burial beneath the water table and as the amounts of alteration products increase. Resistivity values for the unweathered basalts of the Bruneau Formation in the survey area were measured beneath soundings $3,2,28$, and 23, and range from about 77 ohm-m at VES 3 to about $295 \mathrm{ohm}-\mathrm{m}$ at VES.2. Resistivity values approaching $500 \mathrm{ohm}-\mathrm{m}$ were measured for the near-surface basalts of the Snake River Group and the Bruneau Formation beneath VES 31 (fig. 33). Resistivities for weathered Hawaiian basalts buried beneath the water table have been reported by Zohdy and Jackson (1969) to be as low as 30 ohm-m; Keller and Rapolla (in press) report resistivities as low as $10-20 \mathrm{ohm}-\mathrm{m}$ for sequences of freshwater saturated basalts in other parts of the world. Increased temperature, salinity, and alteration products will further decrease the formation resistivity. Dissolved solids in water analysis of the Bruneau-Grand View-area water wells are generally well below $1000 \mathrm{mgm} / 1$ (Young and Mitchell, 1973), which suggests that the low resistivity of the Banbury Basalt and Idavada Volcanics in the 1-7 ohm-m unit is probably due to a combination of high-temperature water and increased amounts of alteration products that would tend to form in a hydrothermal environment. 
The source of the thermal fluids is unresolved but it seems likely that they rise along basement faults, many of which are interpreted to be present along profile $A-\dot{A}^{\prime}$ and are transmitted laterally in the permeable layers. One such source is suggested by the AMT low that extends southeastward into the mouth of Bruneau Canyon. The trend of this low coincides with the rapid thickening of the 1-7 ohm-m layer beneath VES 23 and 24 . Also lying along this trend is a residual magnetic high whose source is relatively shallow, about $1 \mathrm{~km}$ (D. R. Mabey, oral commun., 1974). The magnetic high could be caused by hypogene enrichment of magnetite above the postulated fault zone. The major portion of the magnetic high lies south of the sounding profile, although a nose of the anomaly does extend beneath VES 23. The thick layer of 7-18 ohm-m material underlying the 1-7 ohm-m layer may also contain thermal waters, but this thick 7.ayer has a lower porosity than the Idavada Volcanics higher in the section and thus has a higher resistivity. If the contact between the highresistivity basement layer and the base of the 7-18 ohm-m layer coincides with the base of the Idavada Volcanics, then thicknesses of Idavada Volcanics greater than $1,200 \mathrm{~m}$ are implied in the vicinity of VES 13VES 16 and VES 2-VES 26.

Although the 8-Hz AMT anomaly appears to die out to the east, electrical soundings show that it extends eastward at least as far as VES 27, where the 1-7 ohm-m layer is about $640 \mathrm{~m}$ thick. The failure of the AMT soundings to detect the continuation of the lower resistivity zone to the east may mean that the zone is restricted laterally and that the $8-\mathrm{Hz}$ AMT resistivities reflect a combination of higher resistivity material to the north and south, in addition to the more conductive material beneath the AMT sounding stations. 
Electrical basement rises to the west between VES 9 and VES 10, coincident with the steep $8-\mathrm{Hz}$ AMT gradient on plate 1, and the resistivities of both the 1-7 and 7-18 ohm-m layers begin to increase west of VES 10, thus suggesting a permeability barrier in that direction.

Profile $\underline{B}-\underline{B}^{\prime}$, extending south from the west end of the AMT low, clearly shows the thinning of the low-resistivity layers and the upfaulting of the electrical basement to the south. Between VES 19 and VES 18 the 1-7 ohm-m layer nearly disappears and the thin section of 1-7 ohm-m material beneath VES 18, about $45 \mathrm{~m}$ thick, probably represents a layer of clay-rich lacustrine deposits of the upper Pliocene Glenns Ferry Formation. The existence of these faults is also clearly shown by the offset on the basalt in wells $10 \mathrm{bddl}$ and $21 \mathrm{cbcl}$ on the profile. Hot water is present in well $21 \mathrm{cbcl}$ and may originate in the $28 \mathrm{ohm}-\mathrm{m}$ Tayer beneath VES 18 that thins rapidly to the south. A steep gradient on the 8-Hz AMT map also occurs between VES 18 and VES 19, reflecting the loss of the low-resistivity horizons mentioned above; however, a bowing of the $100 \mathrm{ohm}-\mathrm{m} 8-\mathrm{Hz}$ contour to the south from VES 18 may indicate that the low-resistivity horizons extend to the southeast, perhaps beneath a greater thickness of overburden or simply with increasing resistivities. 
Two soundings, VES 30 and VES 31 , were made north of the main AMT anomaly ( 1.1 ), on the basalt plateau north of Bruneau, to see if any trace of the low-resistivity units could be detected where the increased overburden thickness might screen them from the AMT soundings. Both VES 30 (fig. 31) and VES 31 (figs. 32, 33) clearly show the presence of a conductor at $A B / 2$ spacings greater than $300 \mathrm{~m}$. Sounding 30 is too distorted by lateral effects to model effectively, but VES 31 , although its rising terminal branch is not developed, suggests a layer of about 3 ohm-m about $250 \mathrm{~m}$ thick, followed by a more resistive layer of perhaps $20 \mathrm{ohm}-\mathrm{m}$. This interpretation sugges ts that the 1-7 ohm-m Tayer is thinner at VES 31 than at any other sounding location, perhaps suggesting that the zone of hot water is pinching out to the north.

Conclusions

The d-c sounding survey confirms the presence of a large conductive section of sedimentary and volcanic rocks underlying the low-resistivity AMT anomaly defined by Hoover. Within the conductive section, resistivity boundaries between sedimentary rocks of the Idaho Group, the Banbury Basalt, arid Idavada Volcanics appear to be entirely obscured, at least where well data are available. True resistivities near these contacts range from about $3-5.5 \mathrm{ohm}-\mathrm{m}$, about 3 to 10 times less than would be expected for similar volcanic rock types saturated with fresh water. Because water samples from wells in the Bruneau-Grand View area are relatively fresh, the greatly decreased resistivities are probably related to a combination of thermal waters and alteration within the volcanic rocks and perhaps also within part of the sedimentary section. 
The $d-c$ soundings trace the low resistivity zone beyond the limits of the AMT survey to the east as far as the town of Hammett, where a zone of $4.4 \mathrm{ohm}-\mathrm{m}$ material $640 \mathrm{~m}$ thick is present. To the west the conductive section terminates about $5 \mathrm{~km}$ east of Oreana, where truncation of the conductive section appears to be related to decreasing lateral porosity. The 1-7 ohm-m conductive section can still be recognized beneath the Snake River Plain between Bruneau and Mountain Home, although the top of the conductor is deeper and the thickness is less than at any other sounding location.

No zones: were recognized on any of the soundings where a highresistivity basement was not detected, with the possible exception of the 21 ohm-m basement layer beneath VES 25, which may be caused by the rapidly thickening sections of low-resistivity material to the east and to the west along the line of sounding expansion. The presence of a high-resistivity basement suggests that thermal fluids probably emanate from greater depths than this survey can resolve, rise along fault zones, of which there appear to be many, and then spread laterally through lithologic units that have sufficient porosity. 
Keller, G. V., and Frischknecht, F. C., 1966, Electrical methods in geophysical prospecting: New York, Pergamon Press, 519 p.

Keller, G. V., and Rapolla, Antonio, in press, Geoelectrical surveys of thermal areas, in Gasparini, A., Civetta, G., Luongo, G., and Rapolla, A., eds., Physical volcanology: New York, Elsevier Press.

Kunetz, G., 1966, Principles of direct current resistivity prospecting: Berlin-Nikolassee, Gebruder Borntraeger, 103 p.

Malde, H. E., Povers, H. A., and Marshall, C. H., 1963, Reconnaissance geologic map of west-central Snake River Plain, Idaho: U.S. Geol. Survey Misc. Geol. Inv. Map I-373, scale 1:125,000.

Young, H. W., and Mitchell, J. C., 1973, Geochemistry and geologic setting of selected thermal waters, pt. 1 of Geothermal investigations in Idaho: Idaho Dept. of Water Adm., Water Info. Bull. no. 30,43 p., 2 pr.

Zohdy, A. A. R., 1974a, Use of Dar Zarrouk curves in the interpretation of vertical electrical sounding data: U.S. Geo1. Survey Bu11. 1313-D, (in press).

- 1974b, A computer program for the calculation of

Schlumberger sounding curves by convolution: U.S. Geol. Survey Rept. USGS-GD-74-010, 12 p.; available only from U.S. Dept. Commerce Natl. Tech. Inf. Service, Springfield, Va. .22151 as Rept. PB 232056. Zohdy, A. A. R., Jackson, D. B., Mattick, R. E., and Peterson, D. L., 1969, Geophysical surveys for ground water at White Sands Missile Range, New Mexico: U.S. Geol. Survey open-file rept. 31 p. 
Zohdy, A. A. R., and Jackson, D. B., 1969, Application of deep electrical soundings for ground-water exploration in Hawait: Geophysics, v. 34, p. $584-600$. 


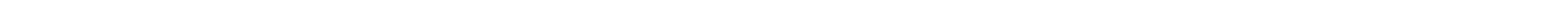




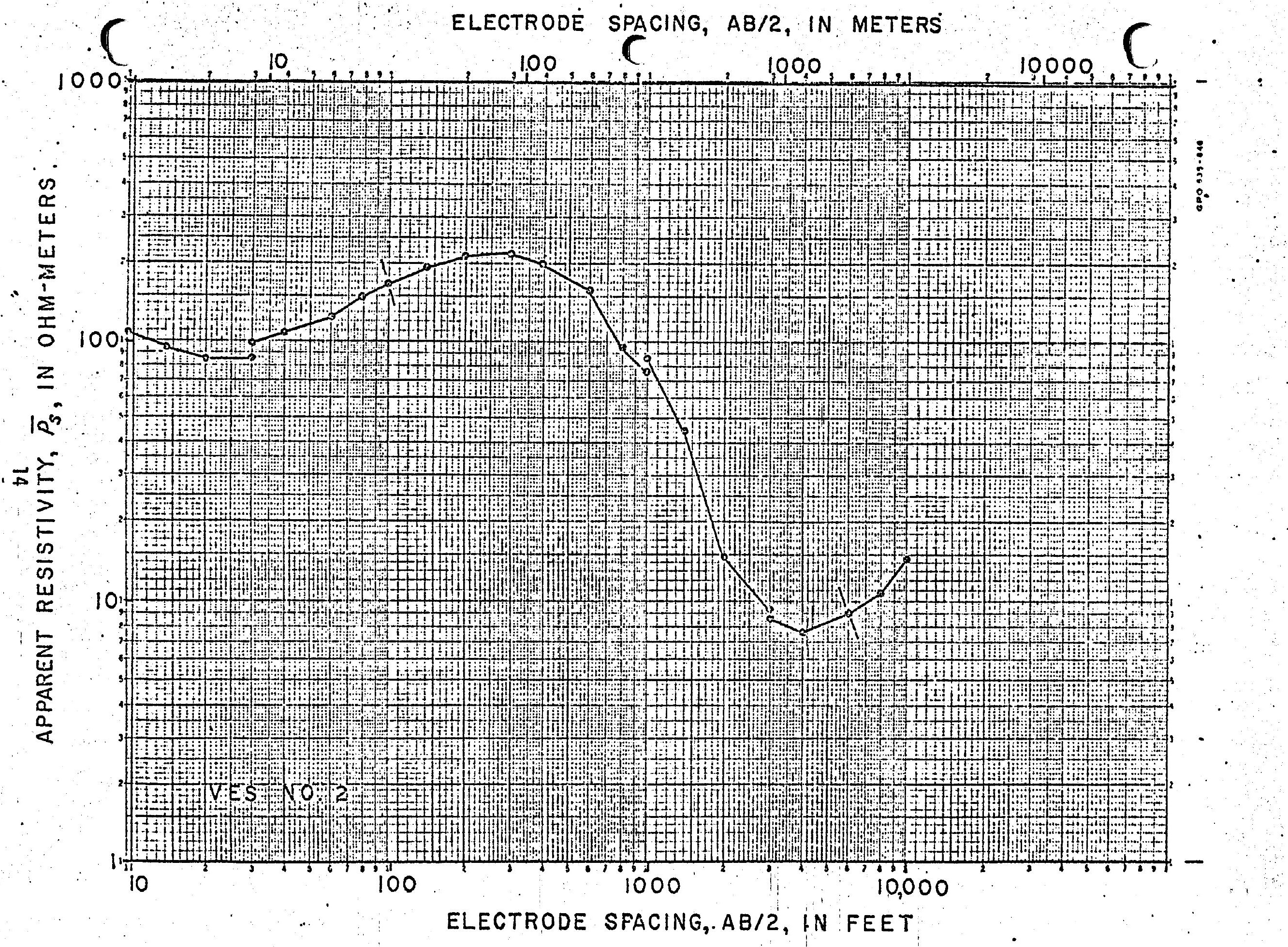

Figure 3.--Schilumberger curve VES 2 




Figure 4.--Schlumberger curve VES 3 . 


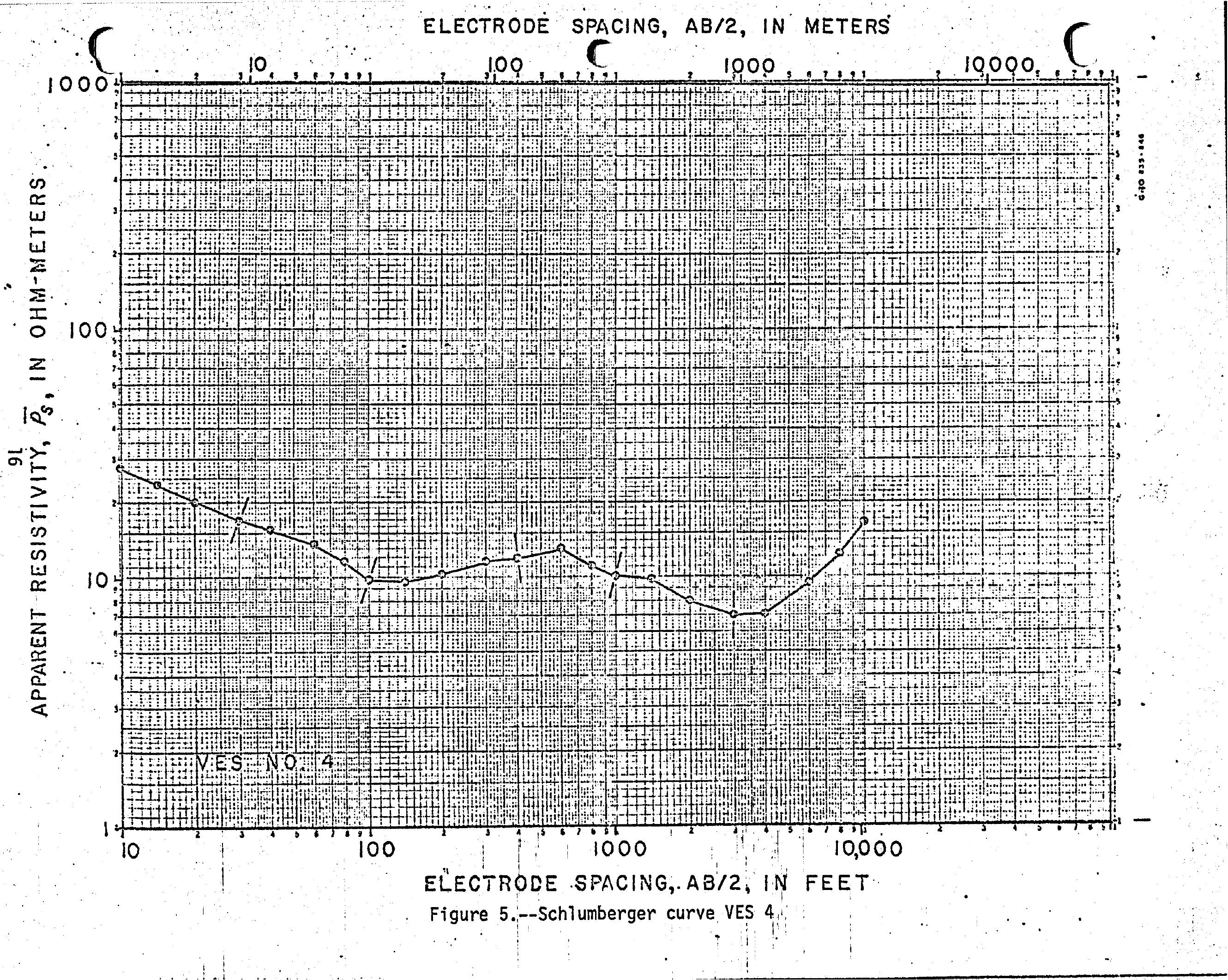




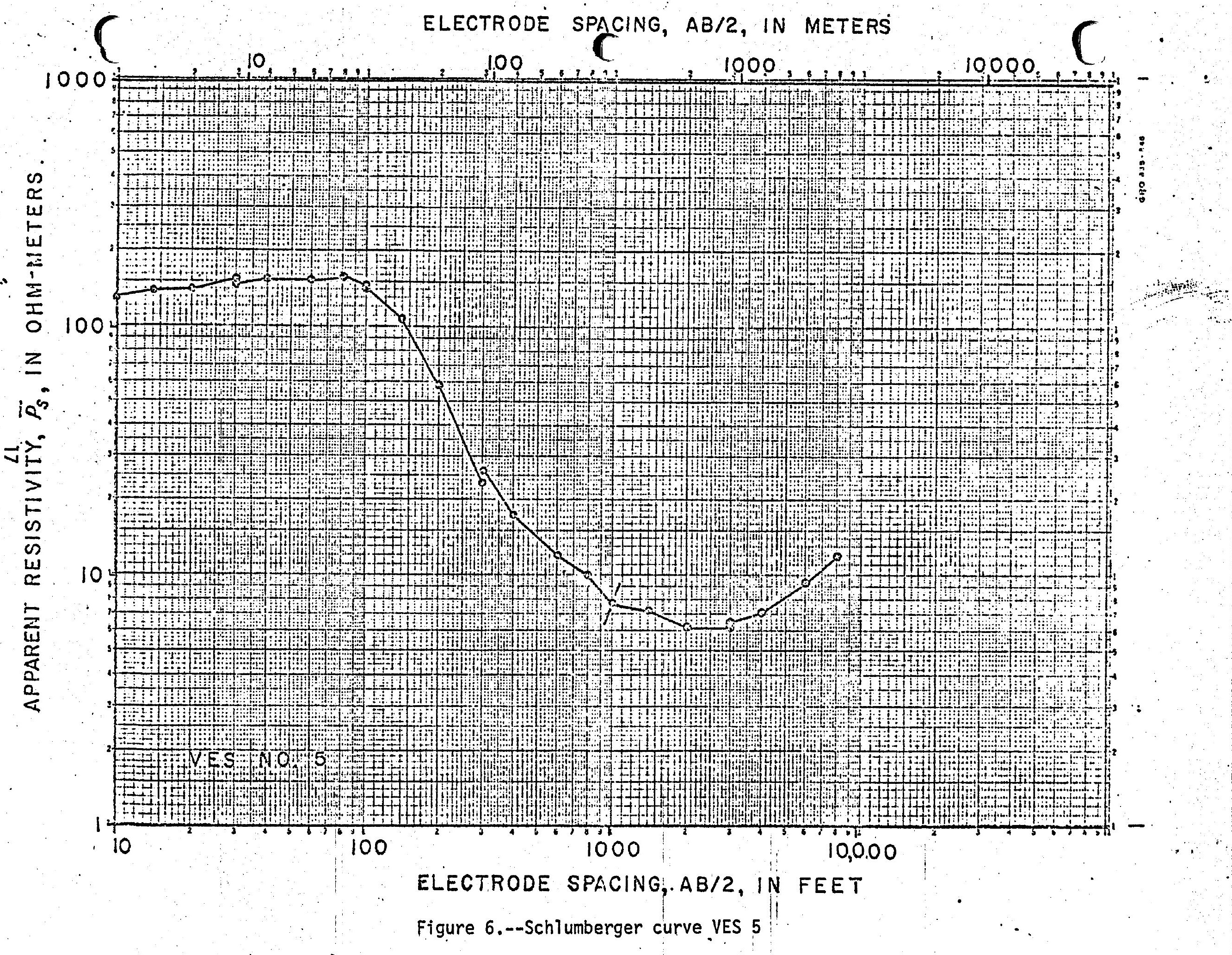




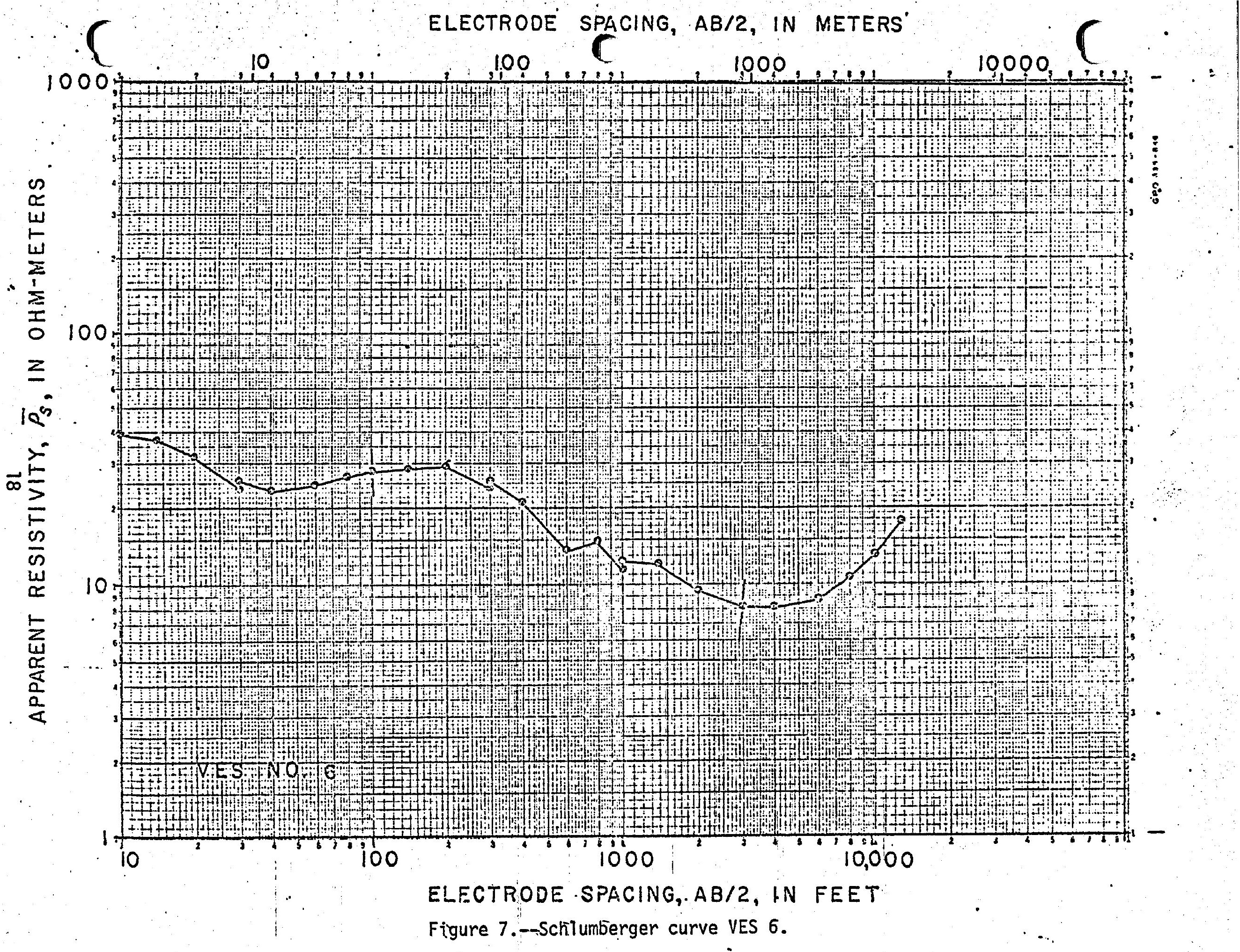




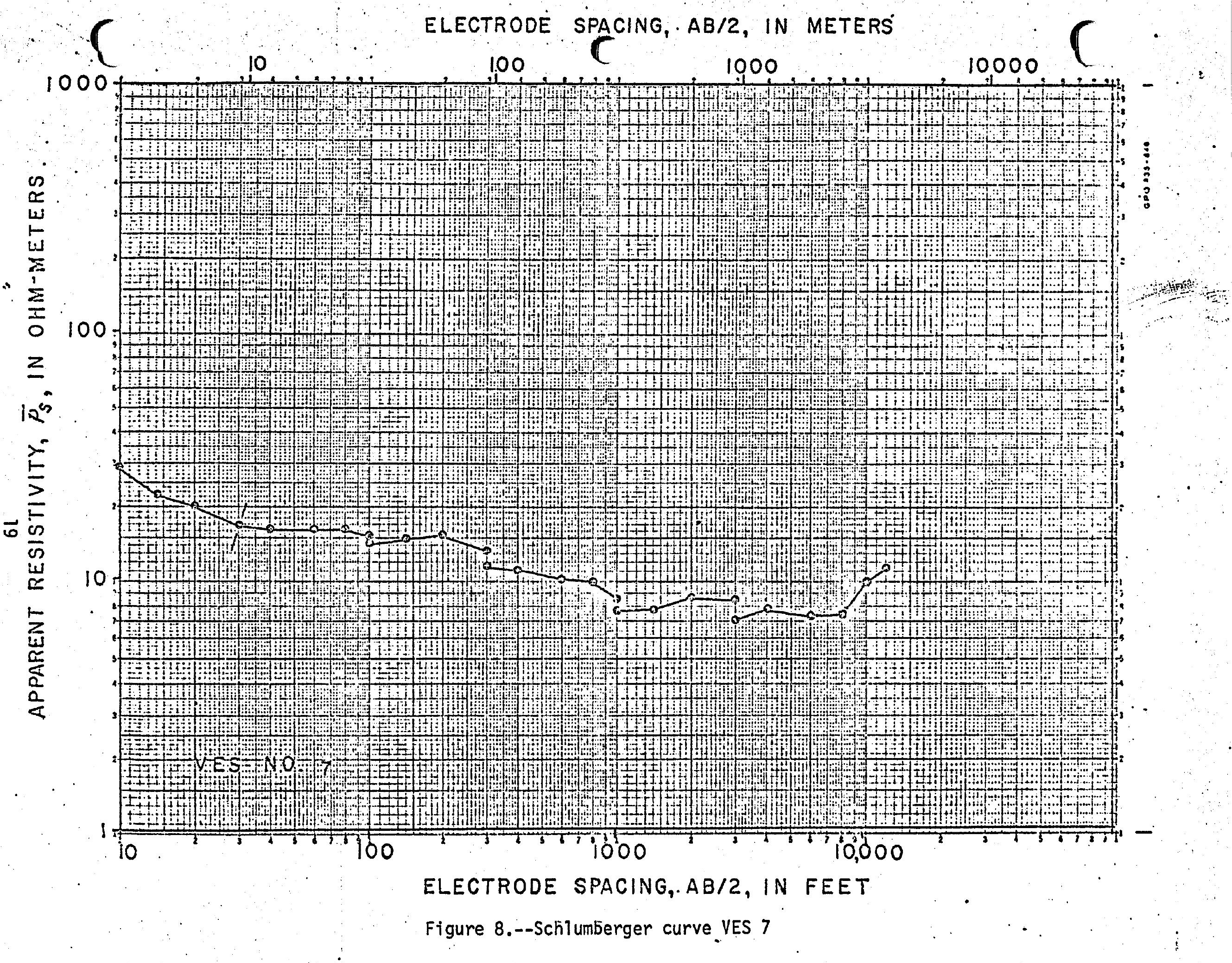




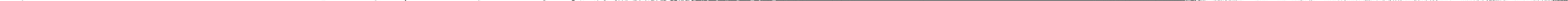


101 10 SHACING, AB/2, IN METERS

$+1,1000$

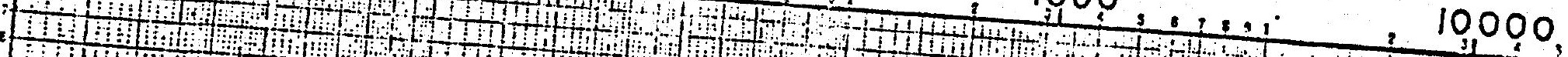

: A t+t:

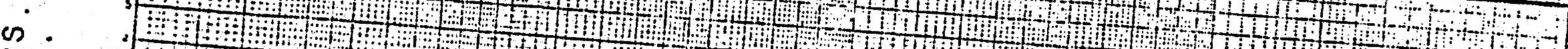

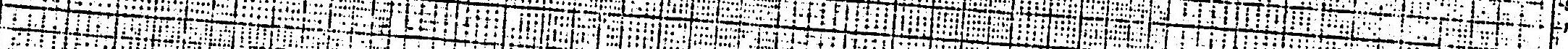

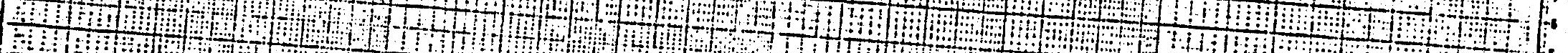
7. 19 If a

5

$\underline{w}$

$\pm$

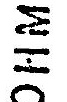

100

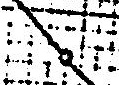

z

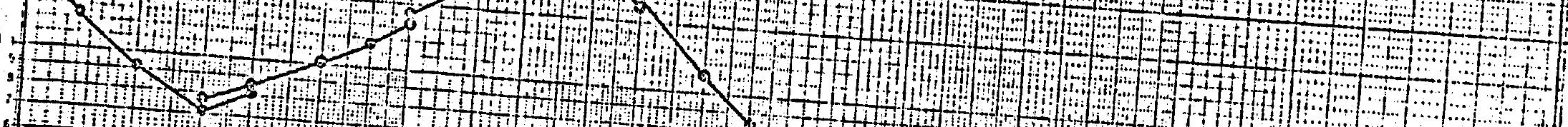

\section{ins}

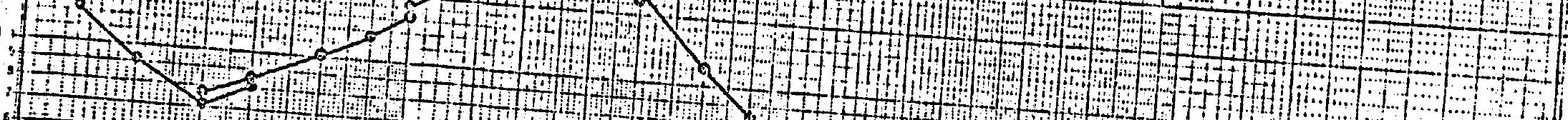

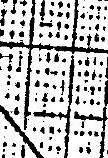

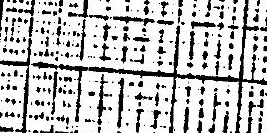

- 1 IIITH

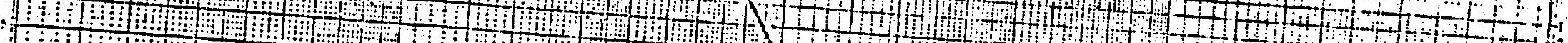
4 a

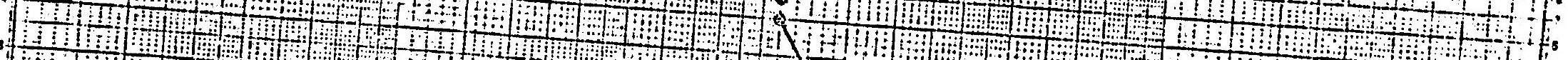

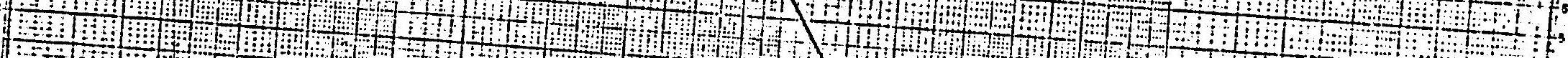

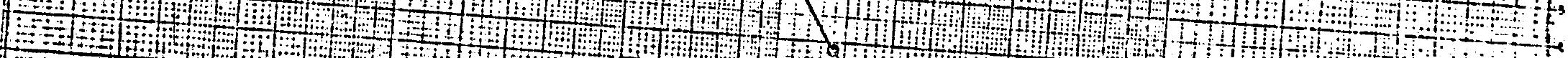

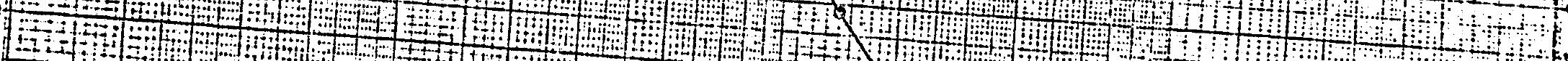

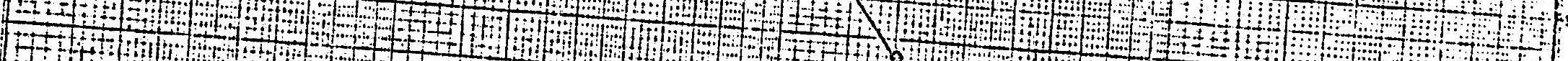
Aft 10.

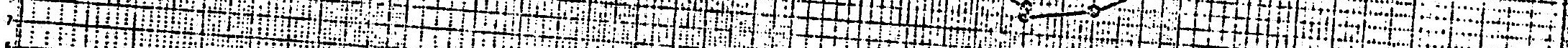

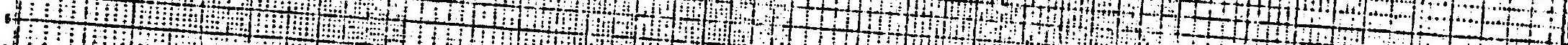
s.

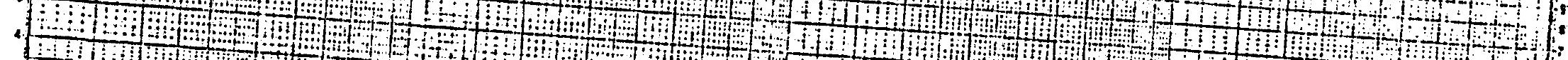

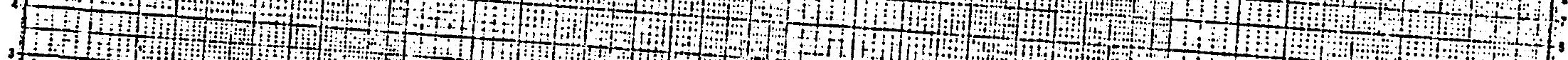

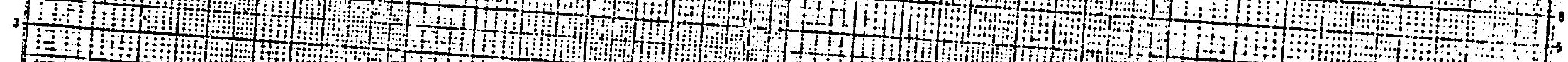

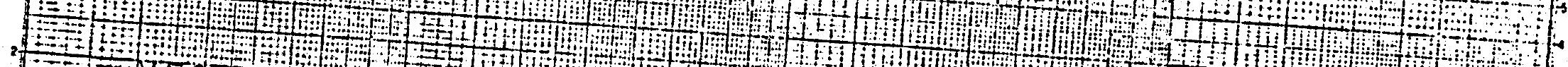

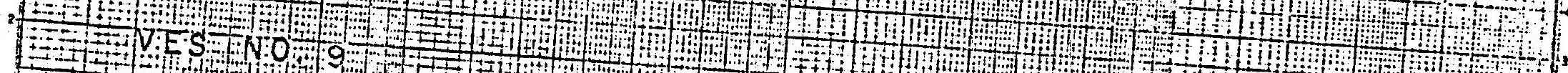

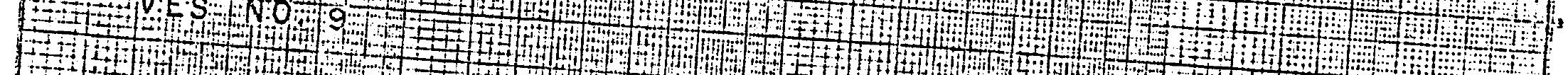

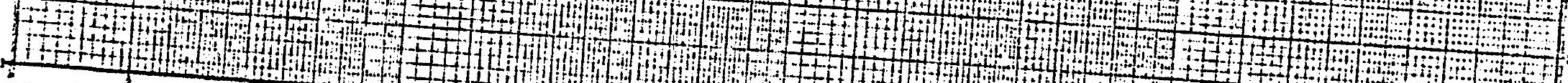
10

$$
100
$$$$
1000
$$$$
\text { ELECTPODE SPACING, AB/2, IN FEET }
$$

, IN FEET

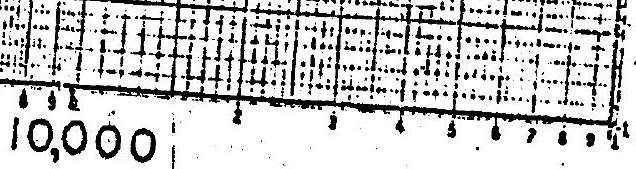

Figure 10.--Schlumberger curve VES 9 


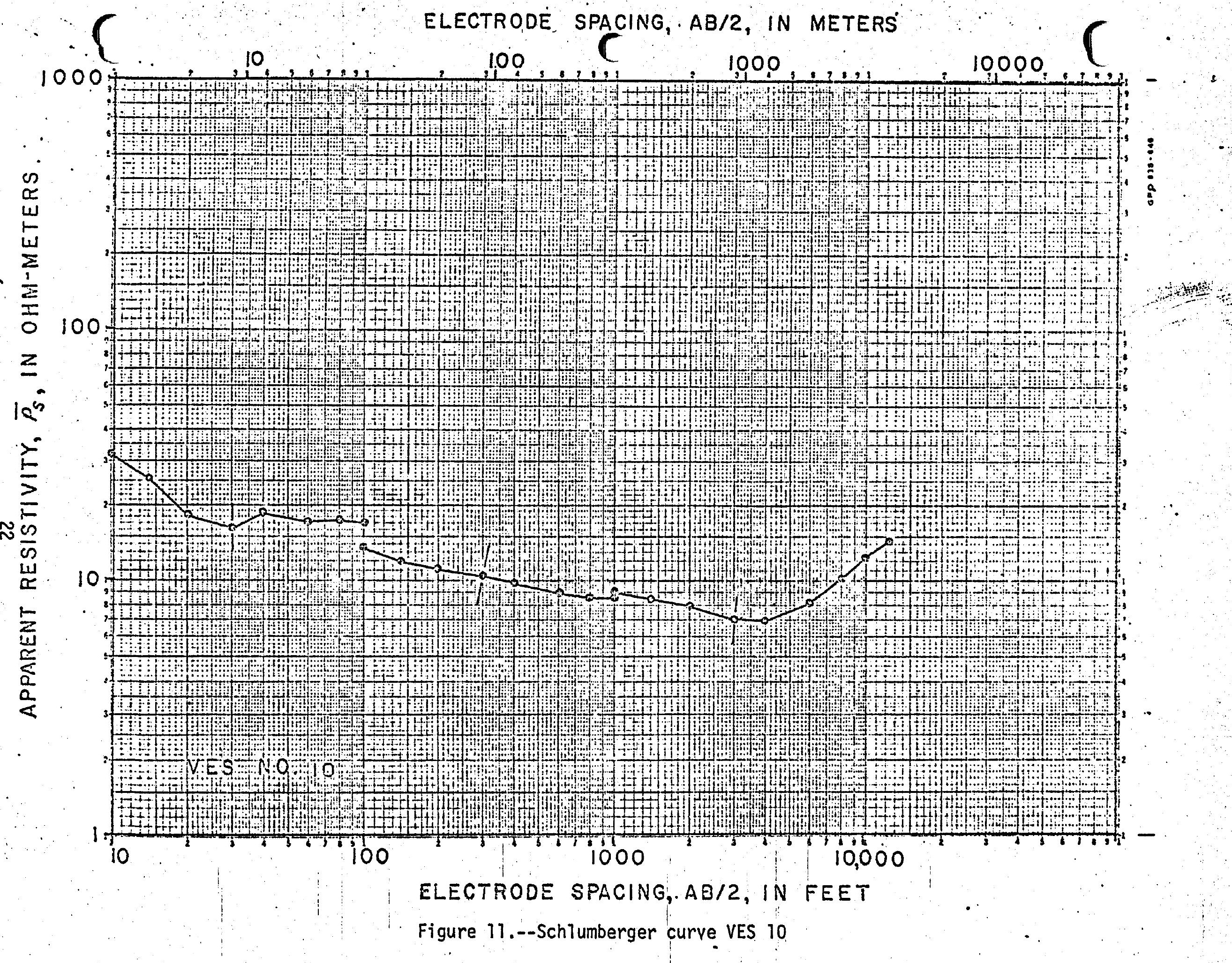




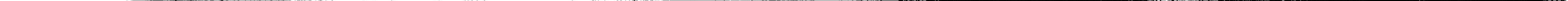




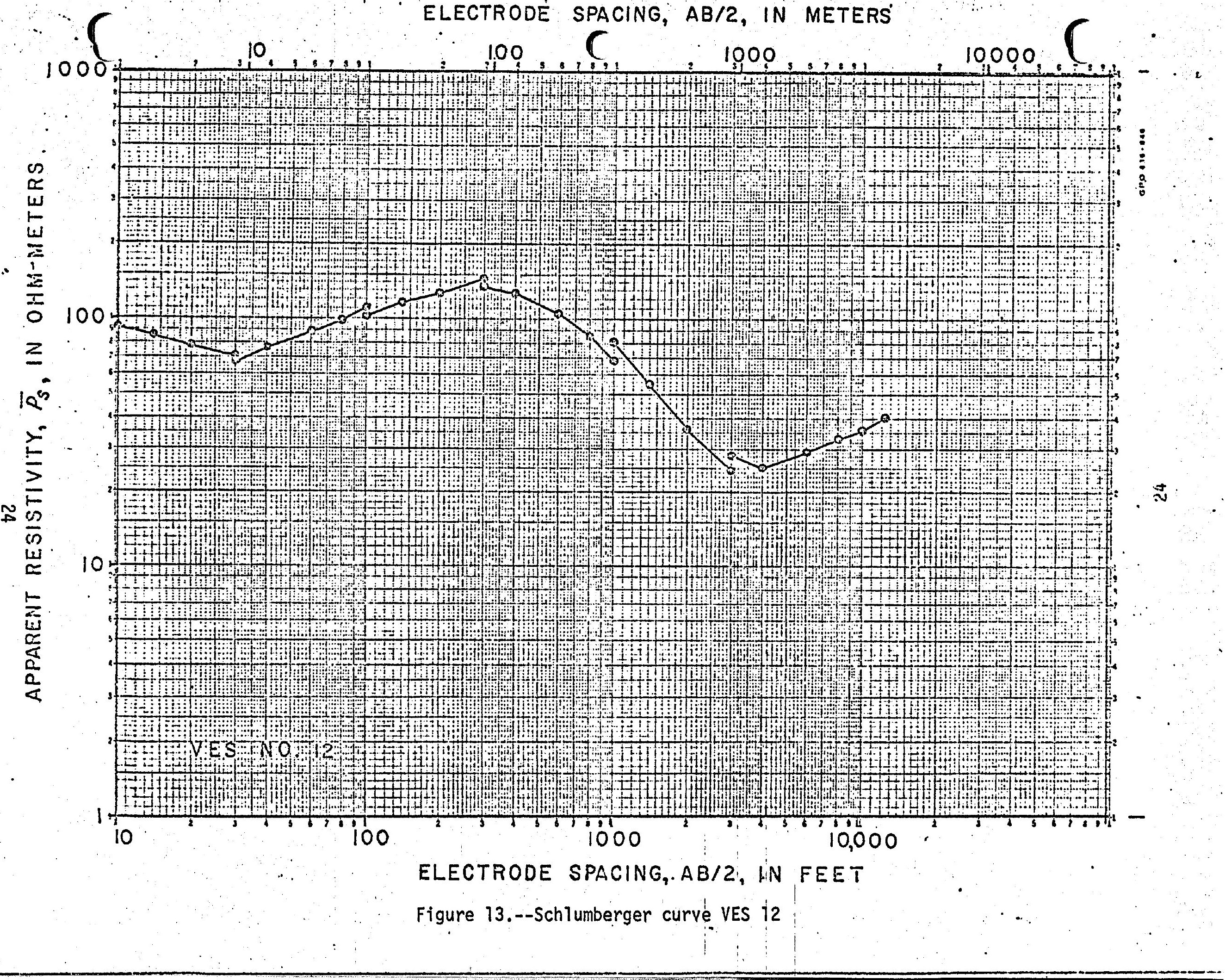




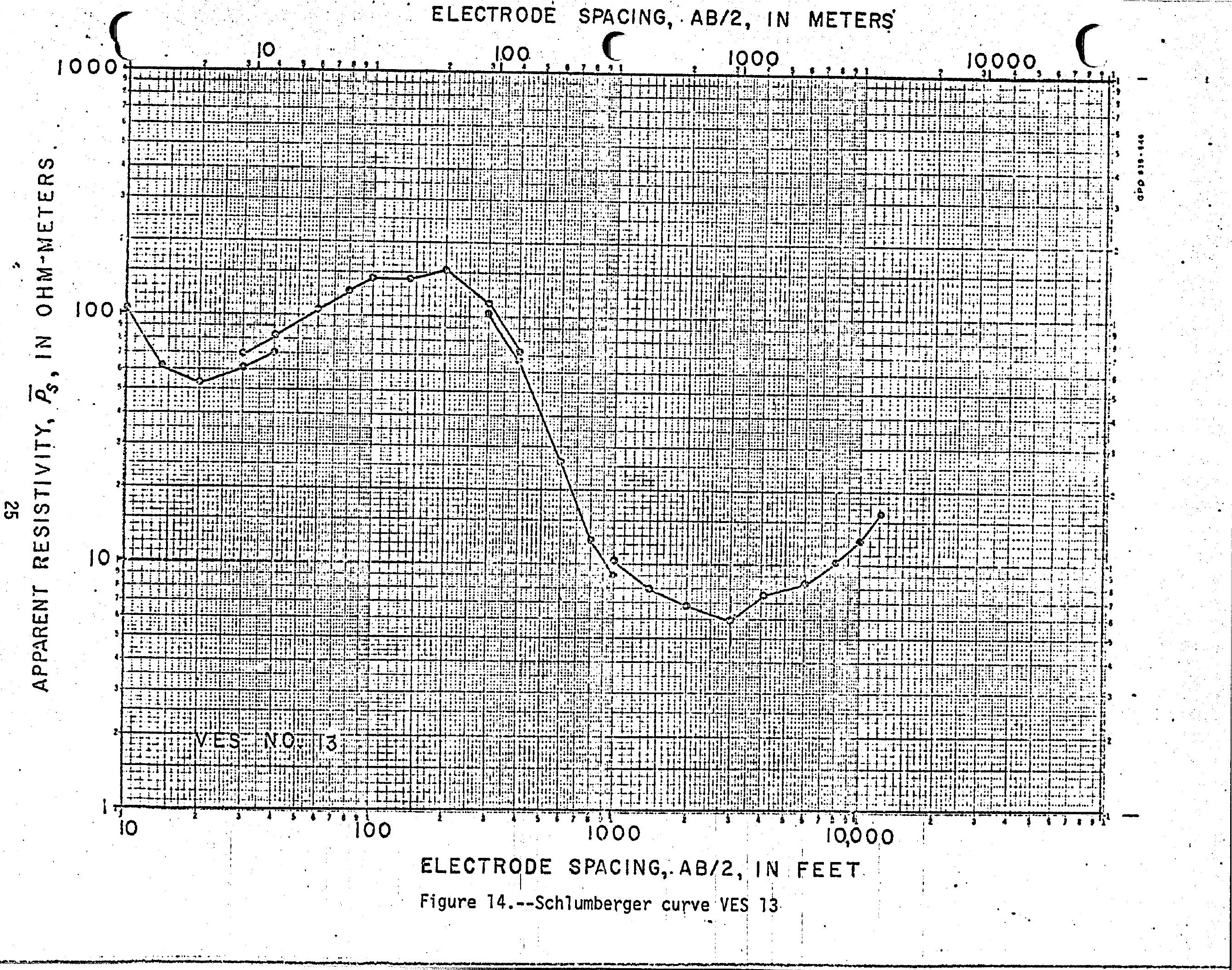




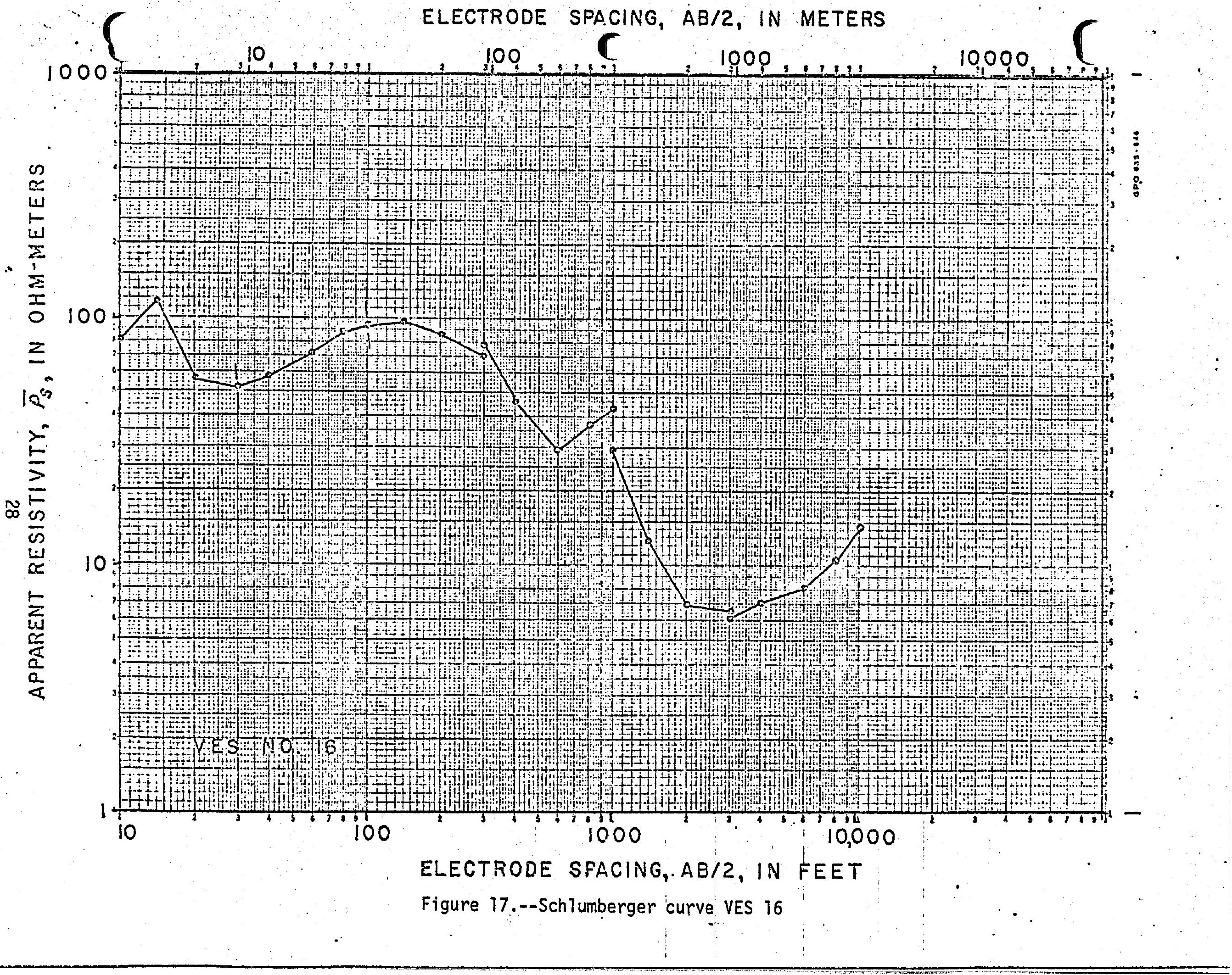




\section{ELECTRODE SPACING, AB/2, IN METERS}

. 10 100

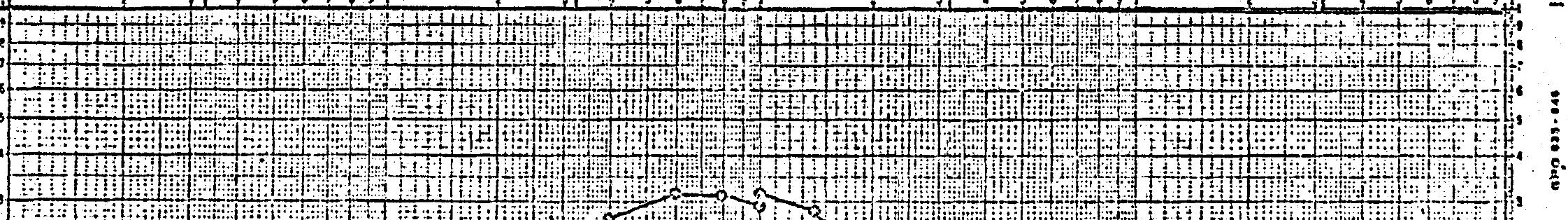

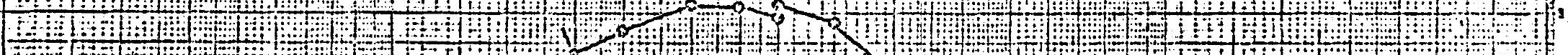

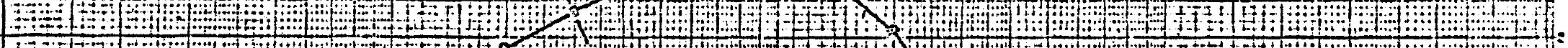

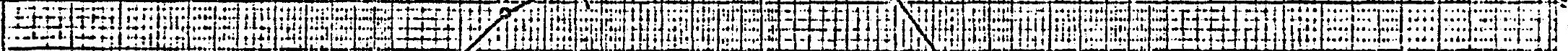
reto tr.t.

100 $+1+4+1+4+1+4$

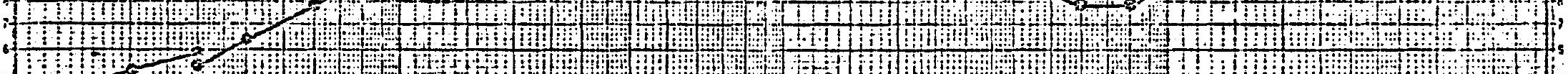

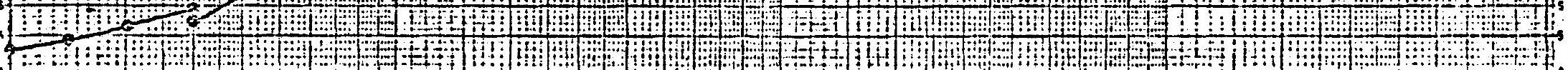
H1 + (m)

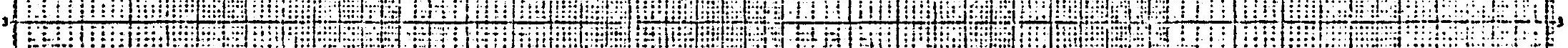

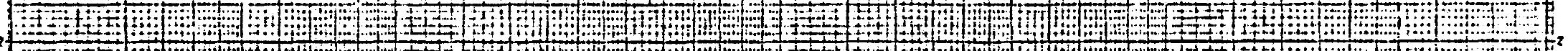

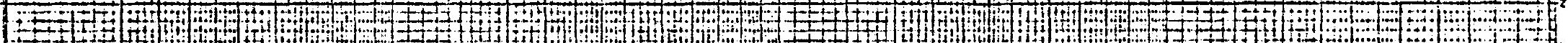
$=-\mathrm{t}$ -

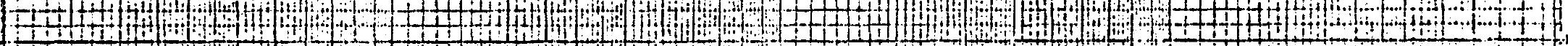

10. (1+1

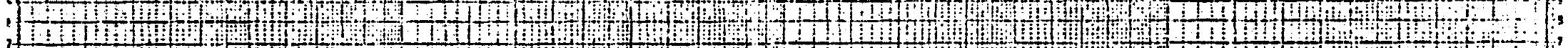

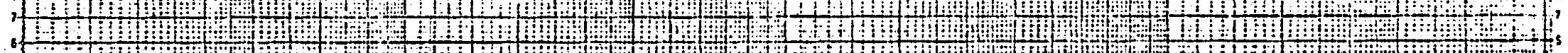
6.

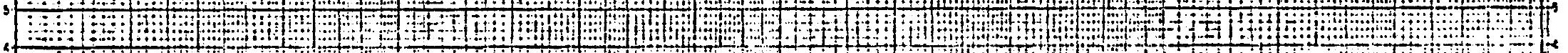

(1,

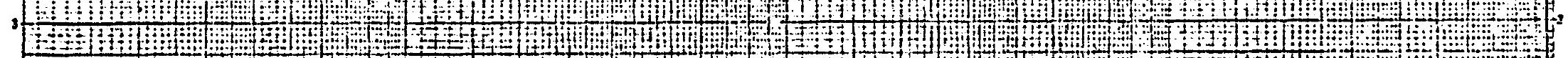
,

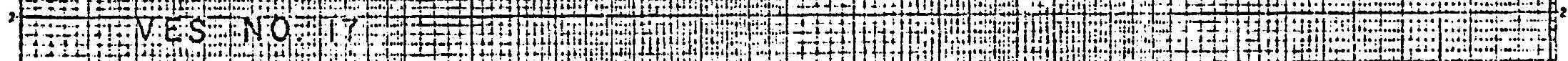

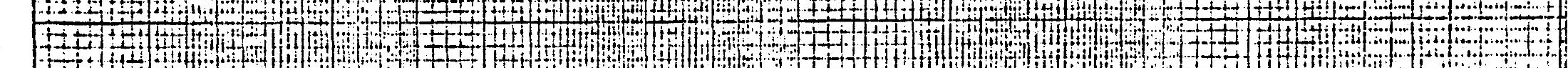

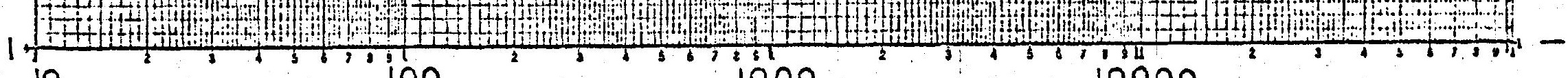
10 100 1000 10,000

ELECTRODE SPACING, AB/2, IN FEET

Figure 18.--Schiumberger curve VES 17 


\section{ELECTRODE SPACING, AB/2, IN METERS}

:H,

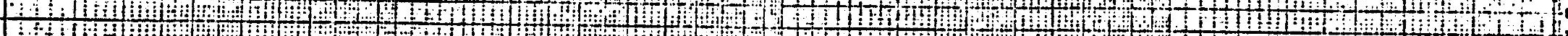
tif :

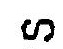

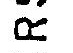

$\omega$

$w$

$\Sigma$

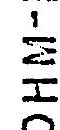

100 4 H.

- 1

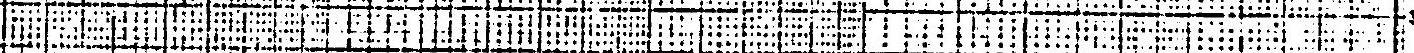

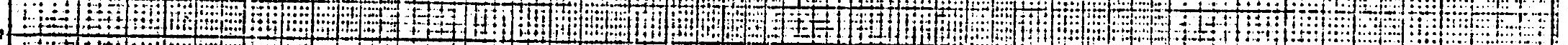

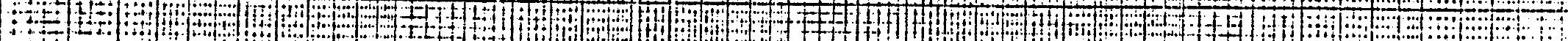

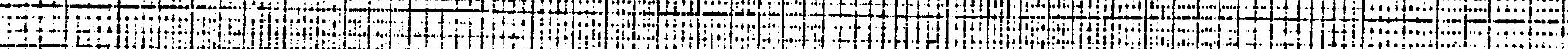

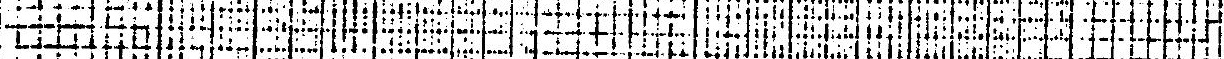

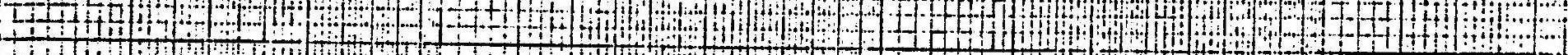
I I T17. if

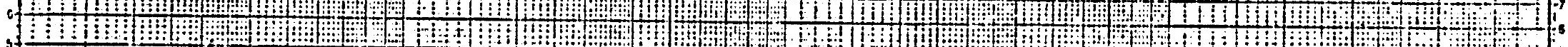

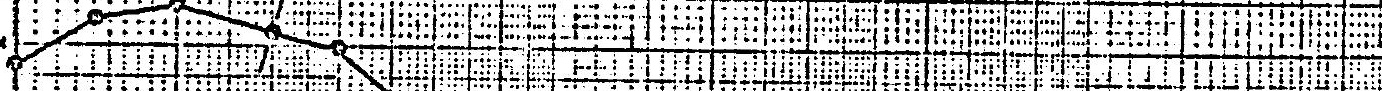

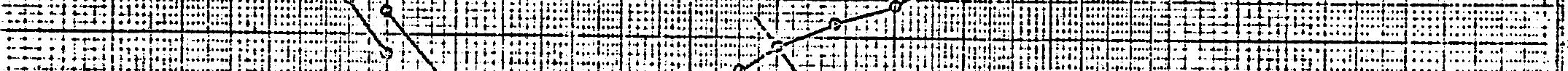

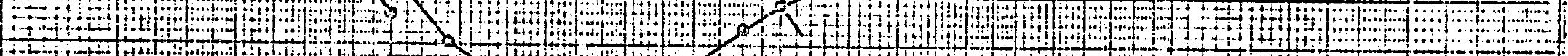

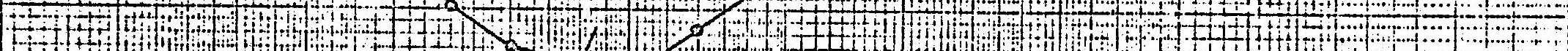

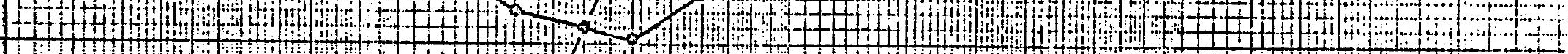

10



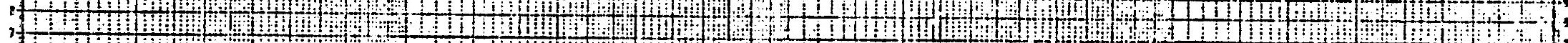

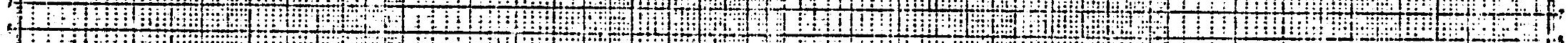

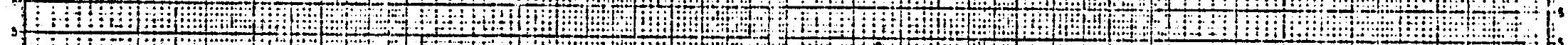
-

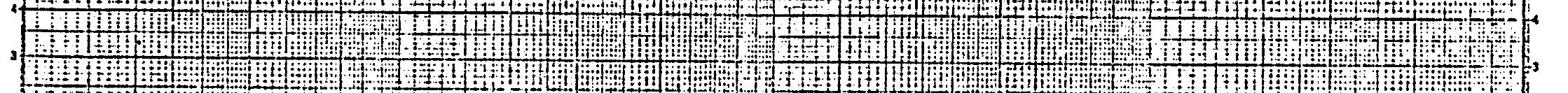

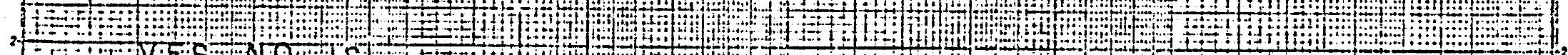

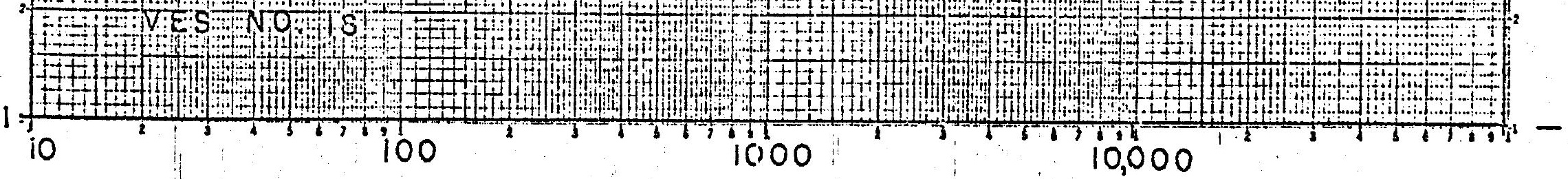

\section{ELECTRODE SPACING,AB/2; IN FEET}

Figure 19.--Schlumberger curve VES 18 


\section{ELECTRODE' SPACING, AB/2, IN METERS}






\section{ELECTRODE SPACING, AB/2, IN METERS}

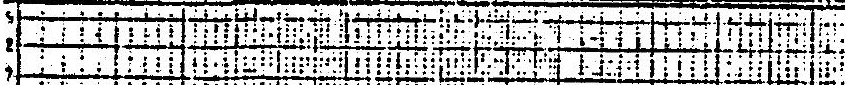
,






\section{ELECTRODE SPACING, AB/2, IN METERS}

000 10 100

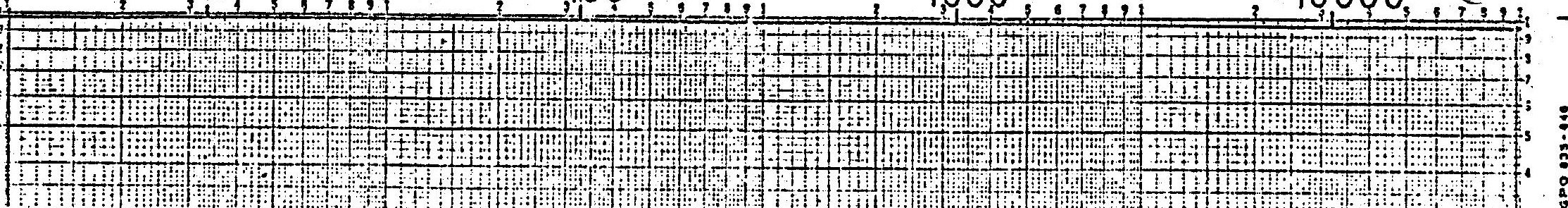
7 72 .

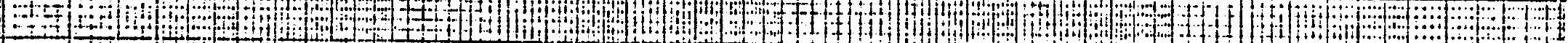

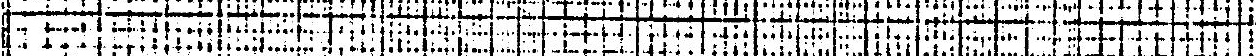
I

100 i

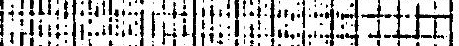

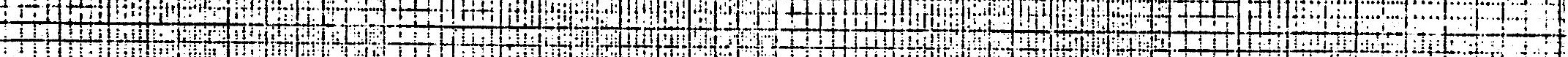
and

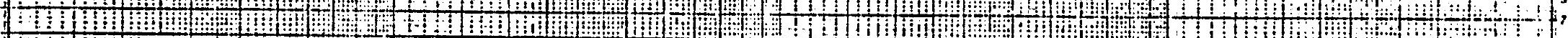

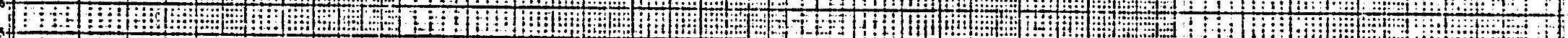

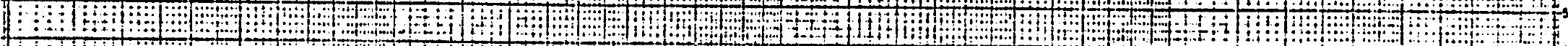
औ

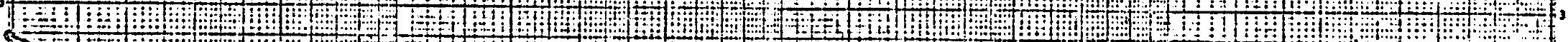

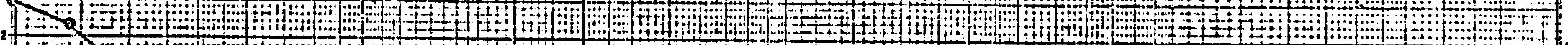
25

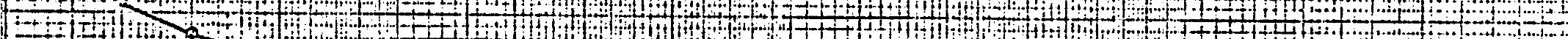

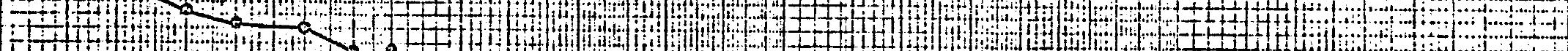

10

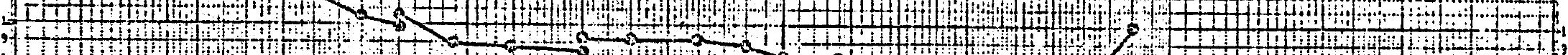

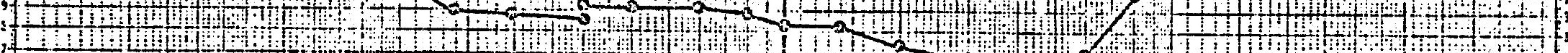

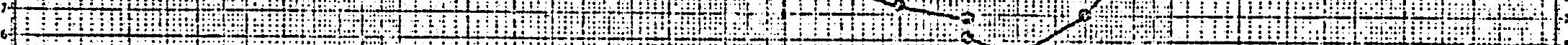

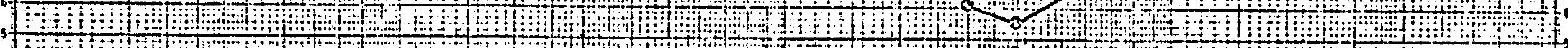
4 -

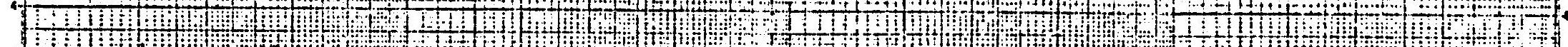

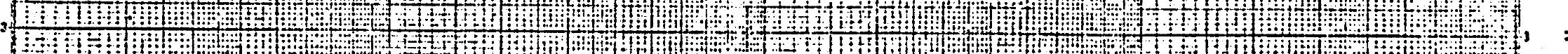

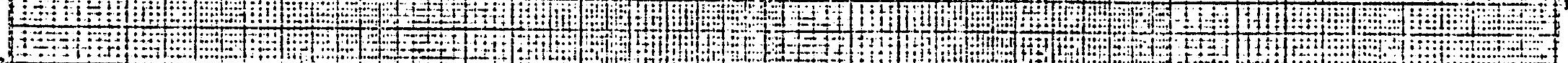
2.

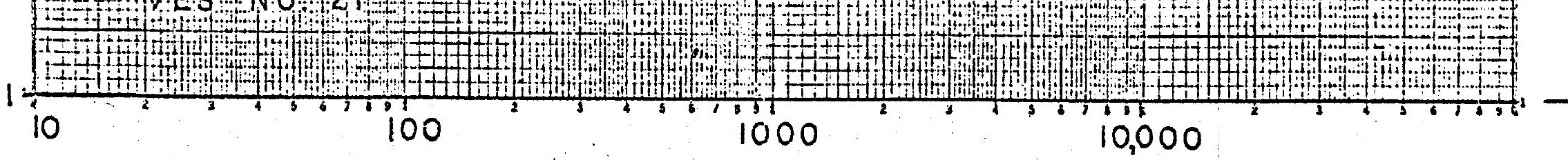
ELECTRODE SPACING,.AB/2, IN FEET Figure 22.--Schtumberger curve VES 21 


\title{
ELECTRODE SPACING, AB/2, IN METERS
}

10, $+100, \ldots$ 1000

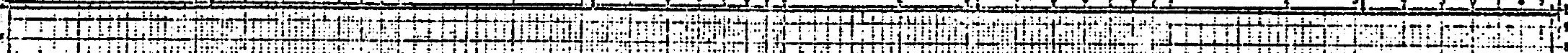

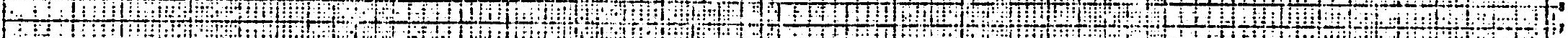

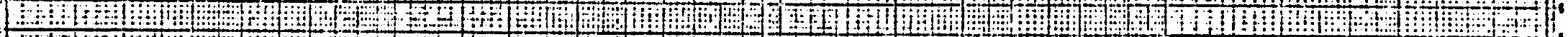

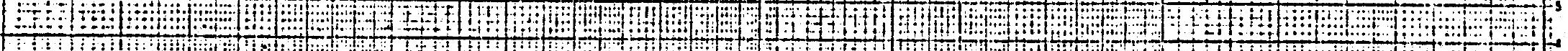

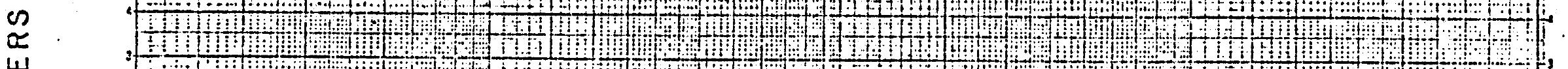

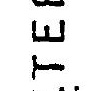

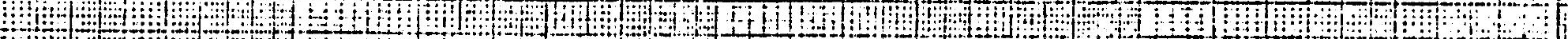
a.

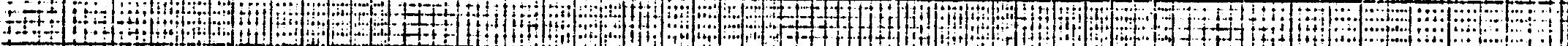

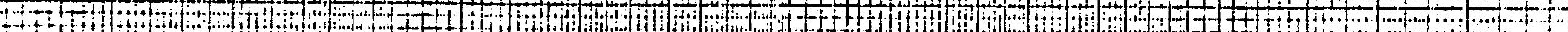

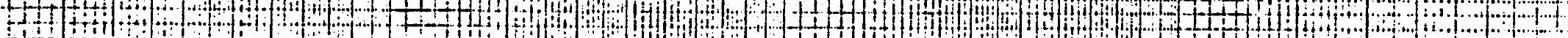

100 H.

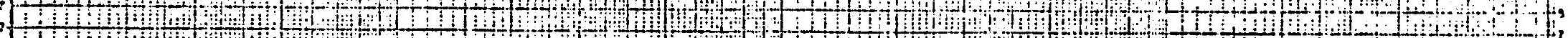

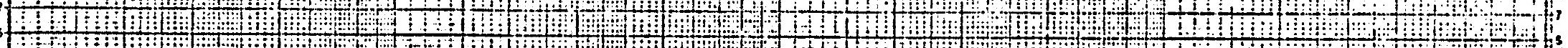

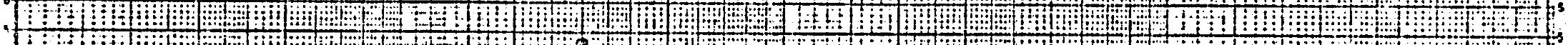

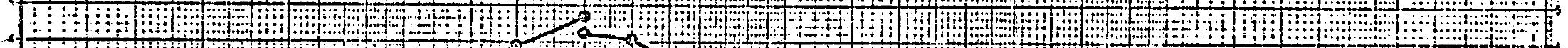

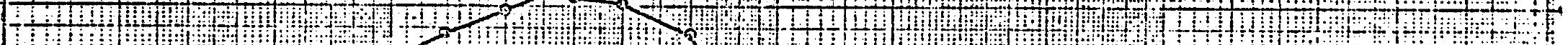

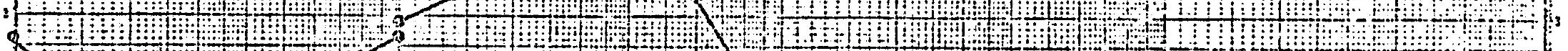

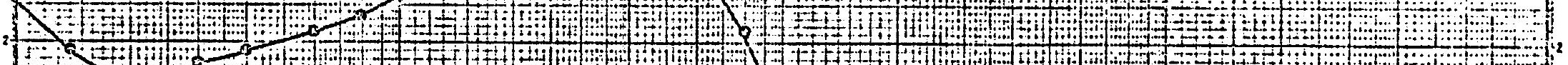
f+C -

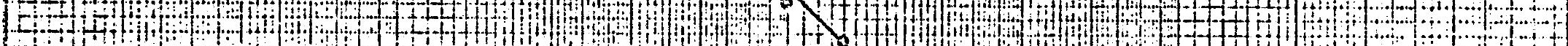

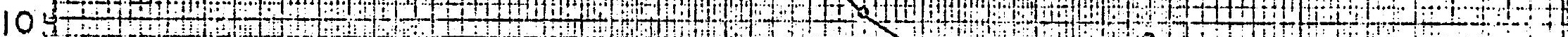

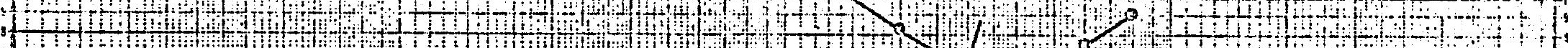



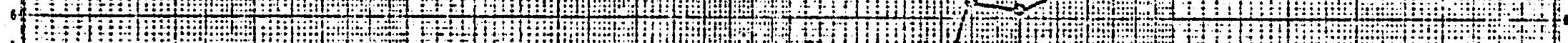
6 a

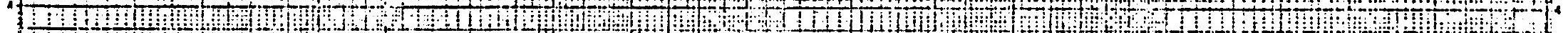

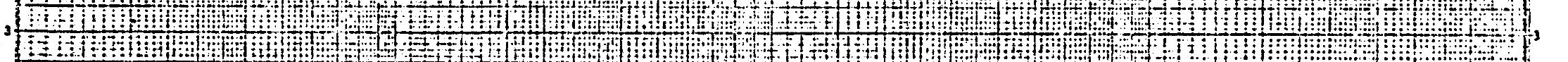

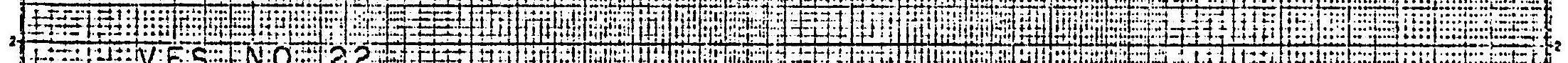

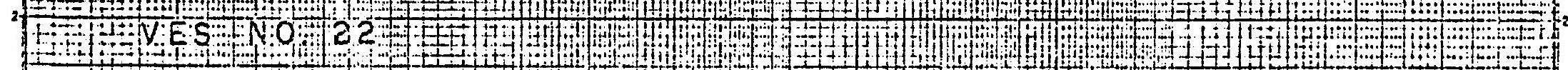
-

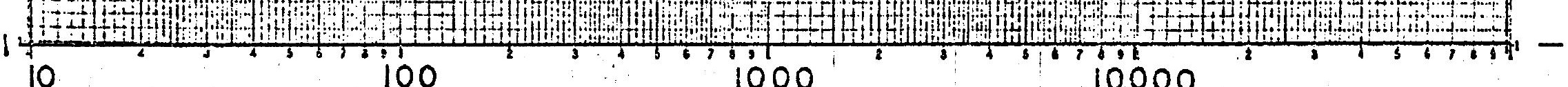

\author{
ELECTRODE SPACING, AB/2, IN 'FEET
}

Figure 23.--Schiumberger curve VES 22 


\section{ELECTRODE SPACING, AB/2, IN METERS}

1000

10 1.00

1000

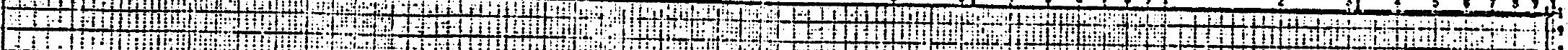
it 1

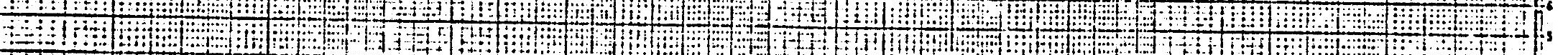

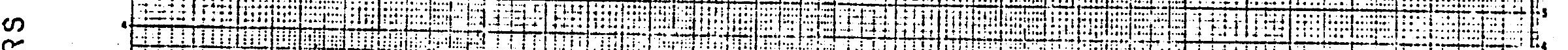

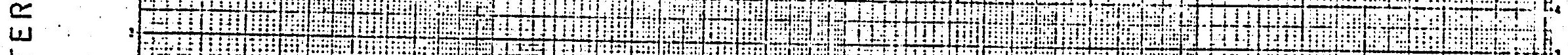

$\omega$

$\pm$

1

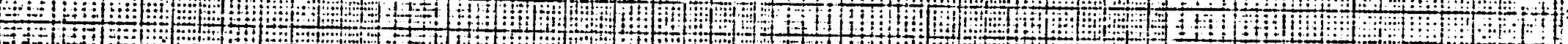

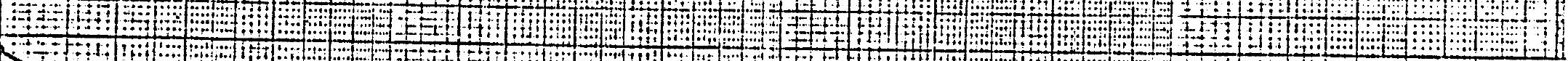
×-1 1

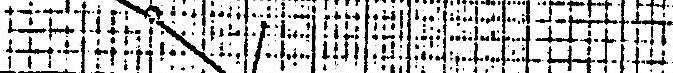

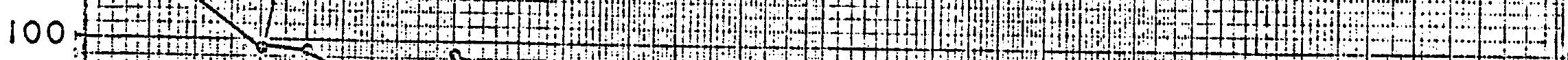
- HifH

\section{o +}

$3 \frac{1}{10}$ (-

\section{(1)}

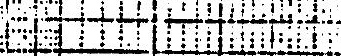
+4.

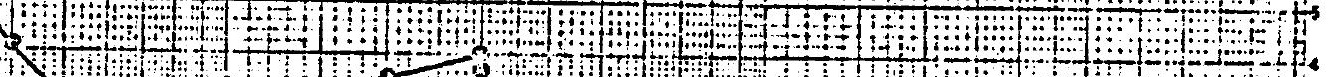

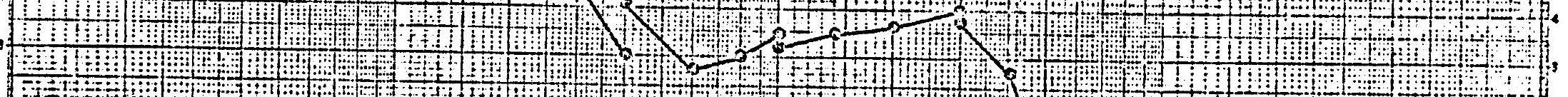
$\frac{1}{2}$

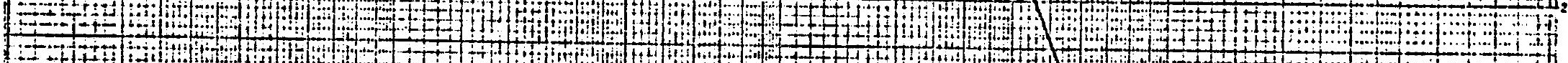

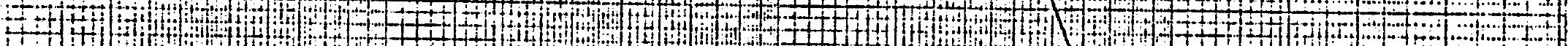

10

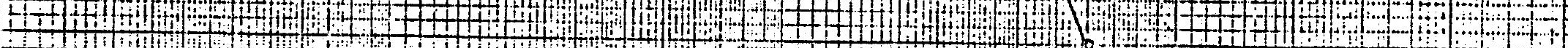
$1 \mathrm{~A}$, f 2. H 30 of - 100 of

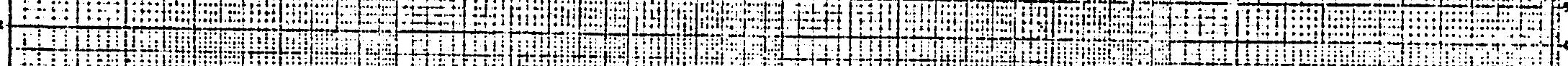
3 a d H

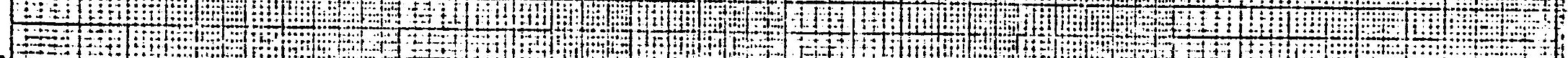

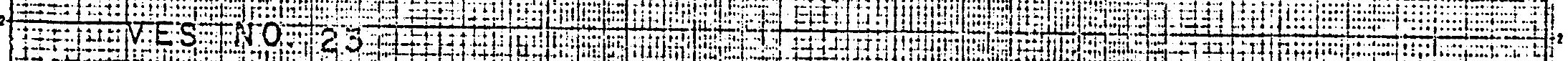

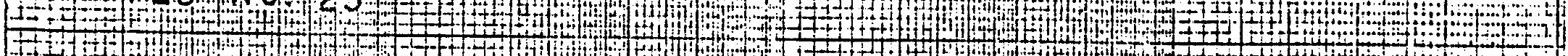

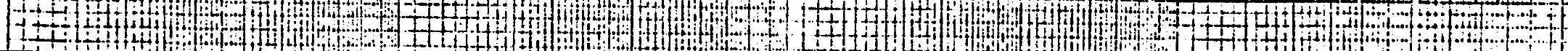

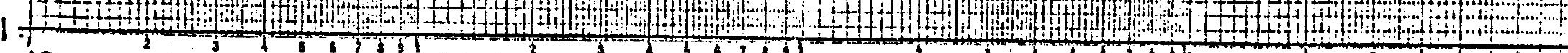
10 100 1000 10,000

ELECTRODE SPACING,.AB/2, IN FEET

Figure 24.--Schlumberger curve VES 23 


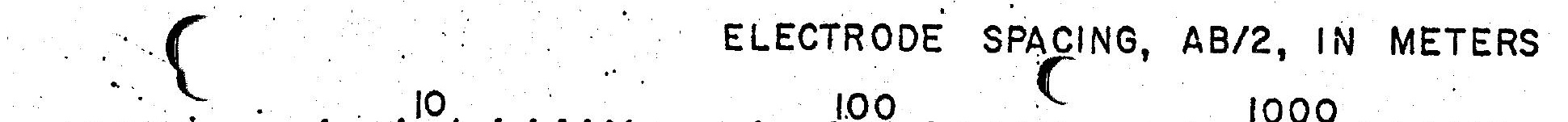

1000

of

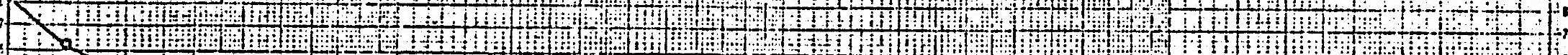
a d a

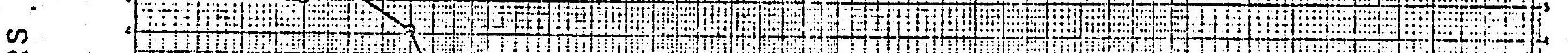

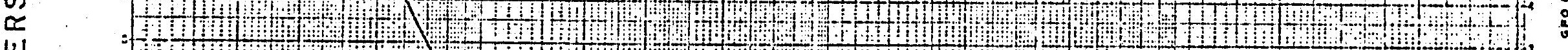

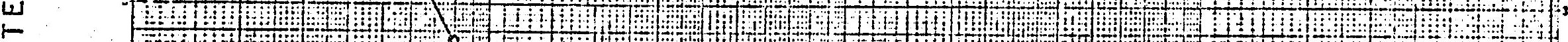
,

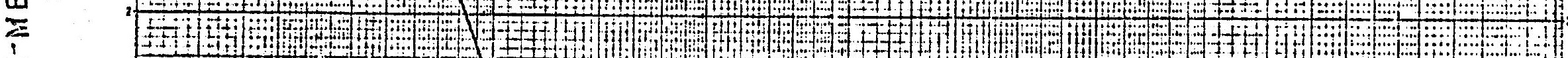

- : 3 if f.

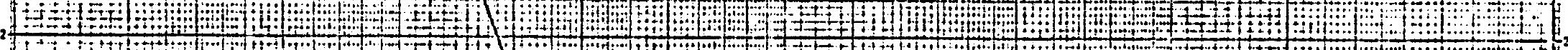
a

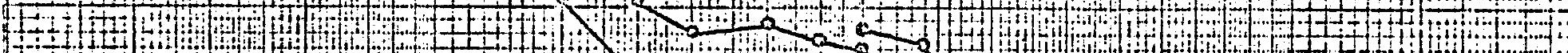
$+1+1+1$

10 ;

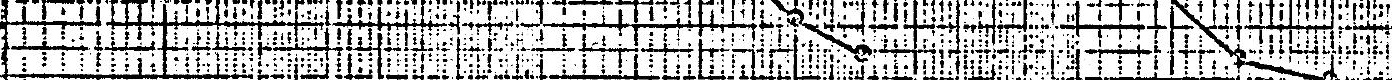

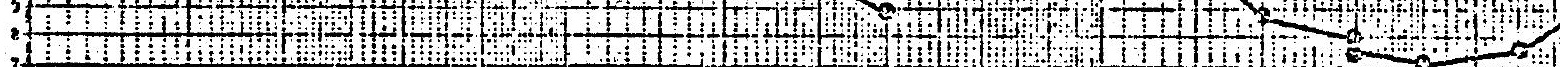

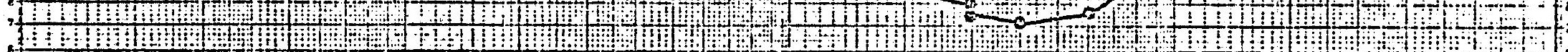

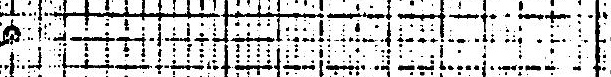

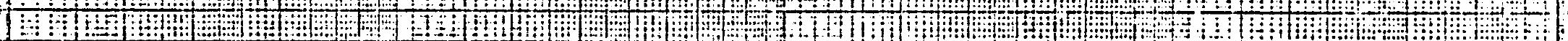

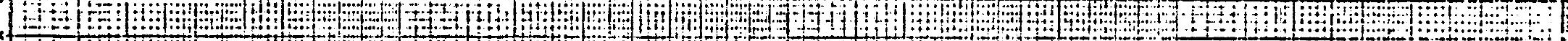
(1)

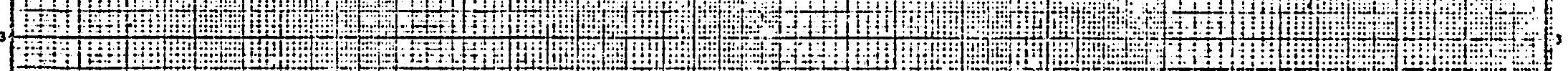

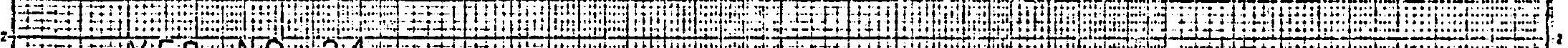

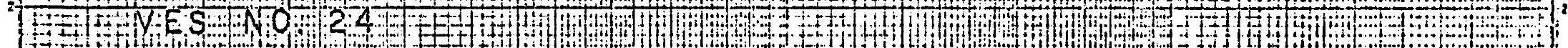

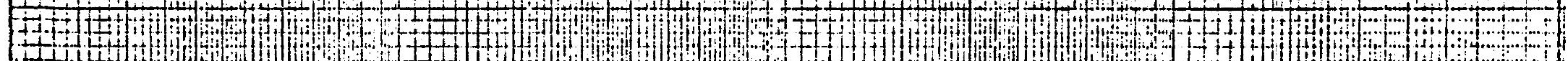
$1+$ 10 100 1000 10,000

ELECTRODE SFACING,.AB/2, IN FEET

Figure 25.--Schlumberger curve VES 24 


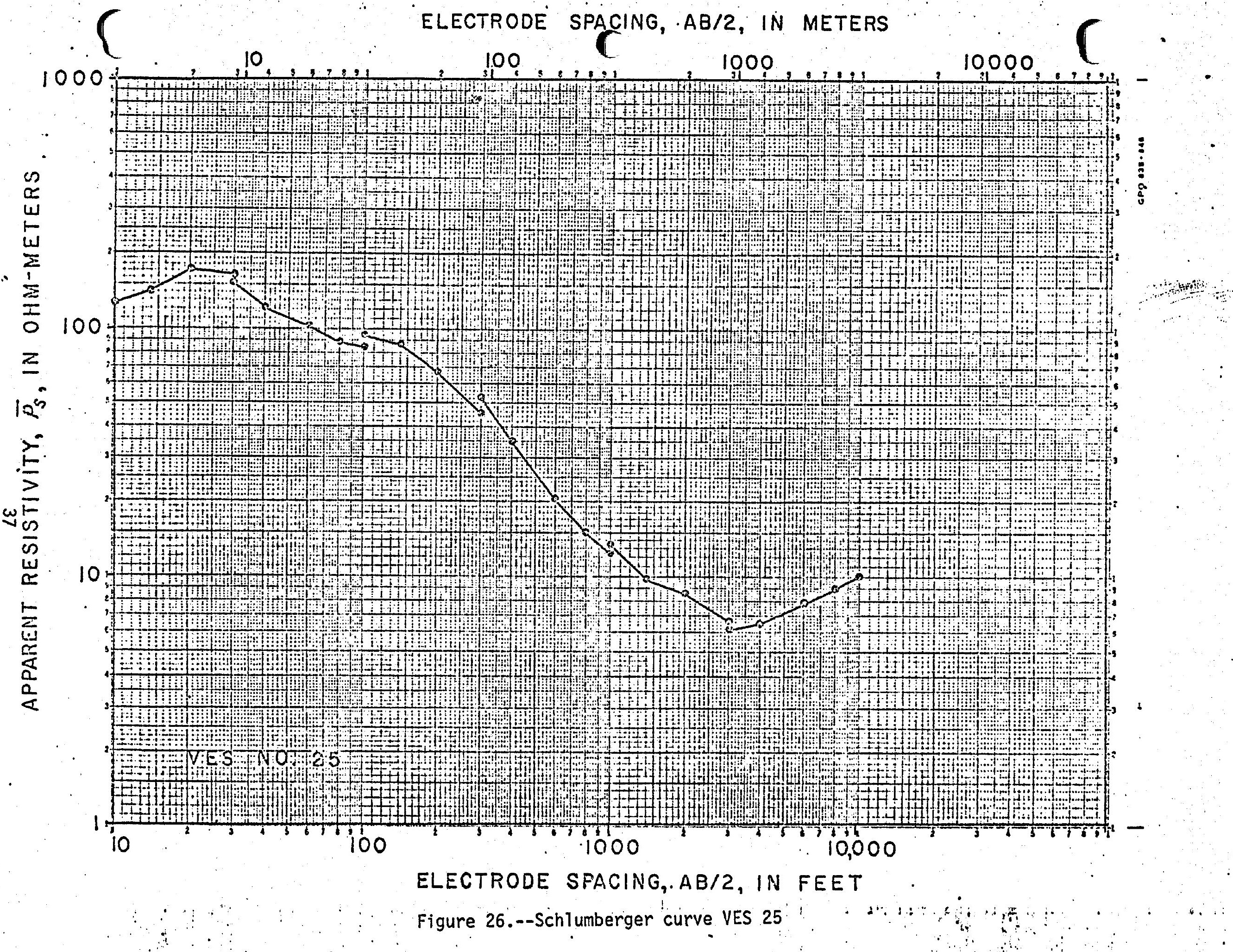




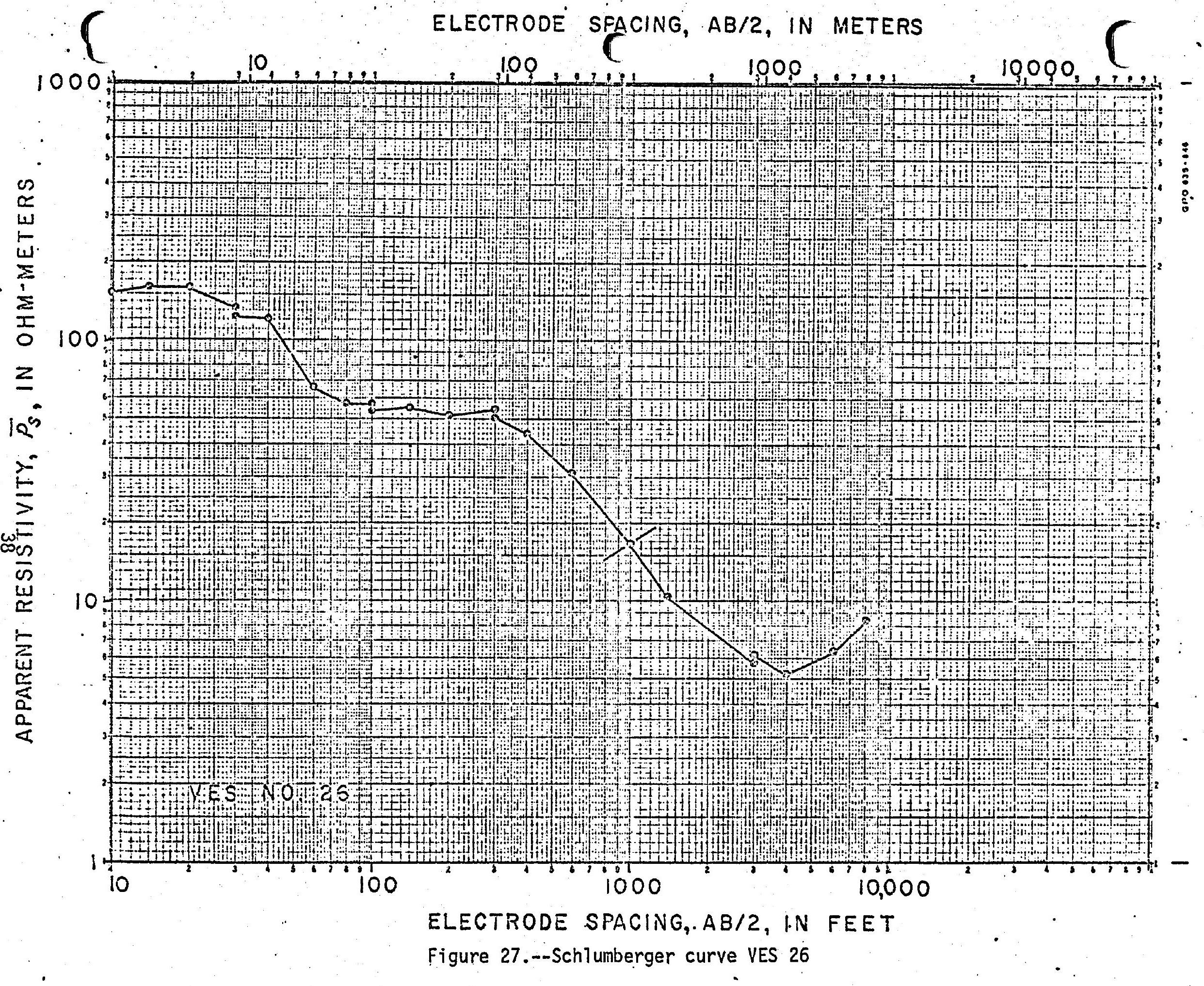




\section{ELECTRODE SPACING, AB/2, IN METERS}

a 1 W H H

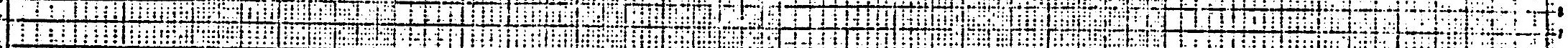

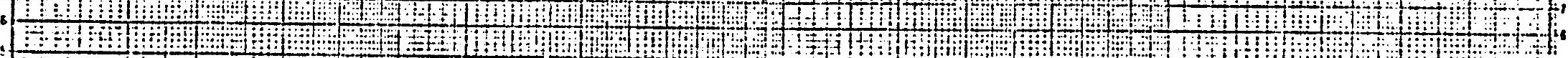

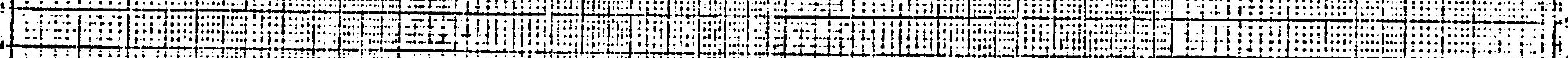
म. 1.

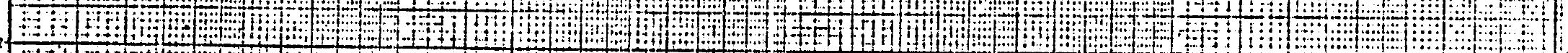

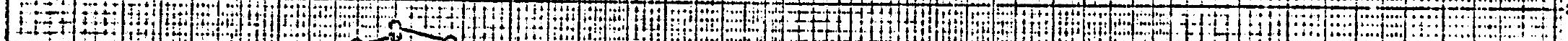

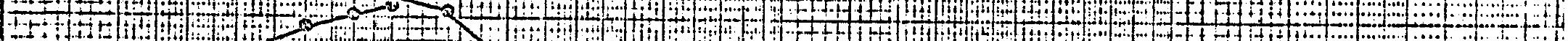

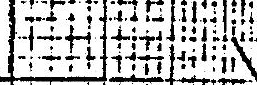

100 intm Hini: $18+1+1$ A

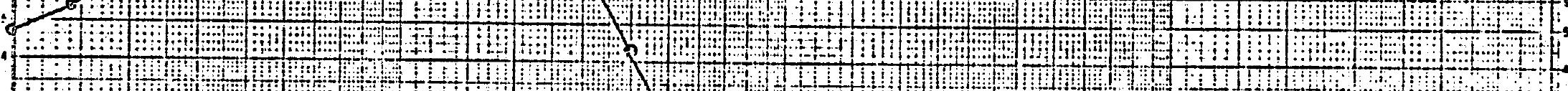

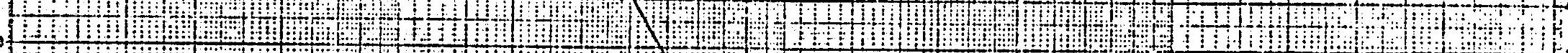

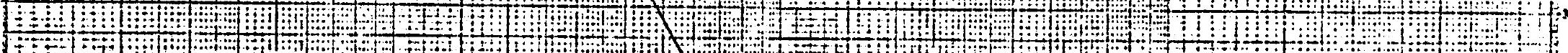

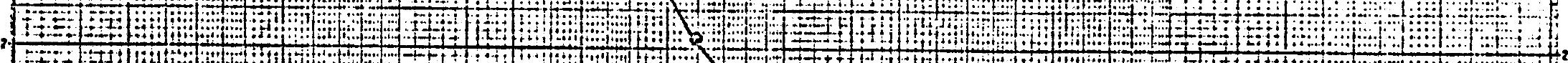
Enth

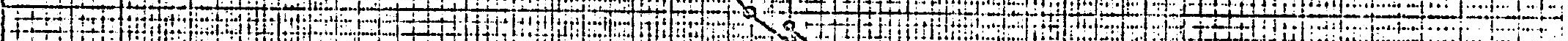

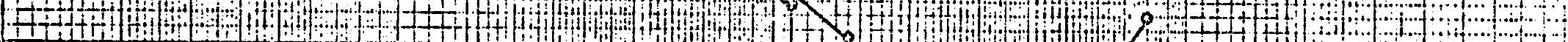

10

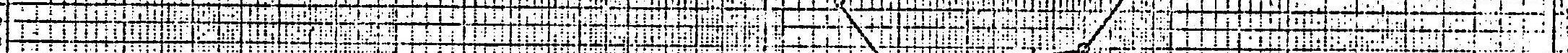

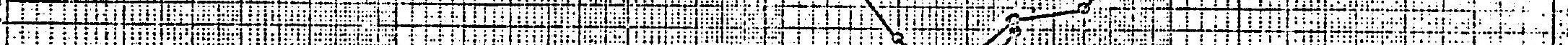

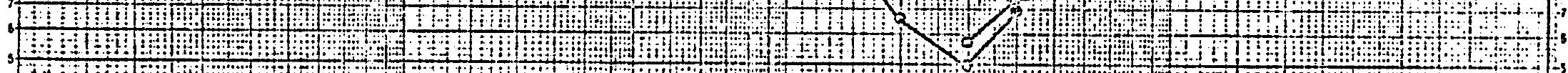

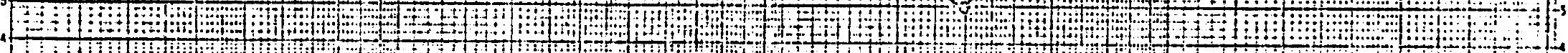

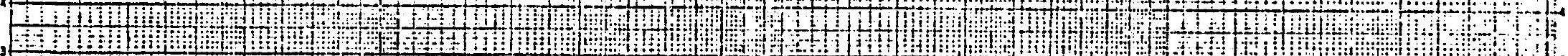

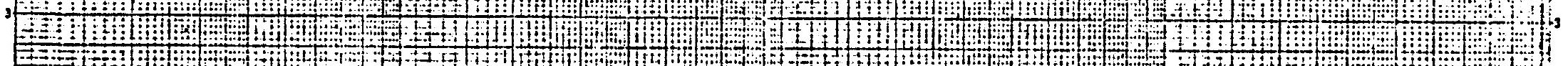

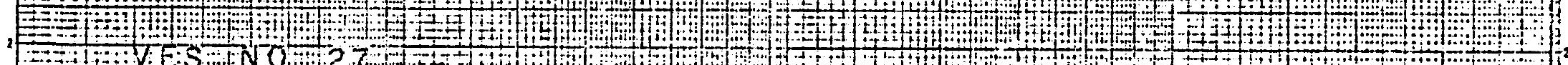

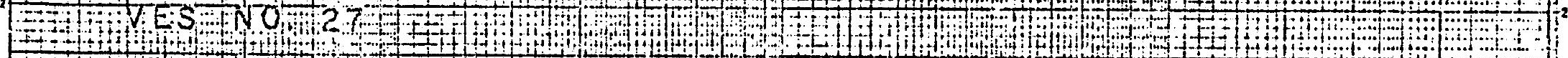

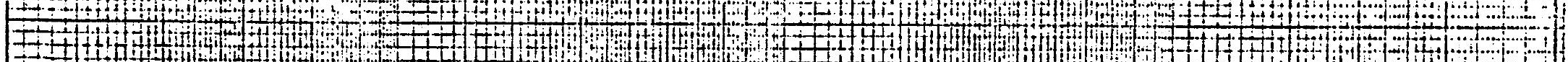

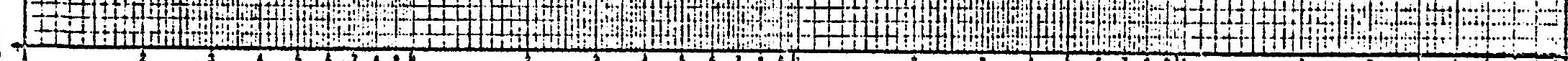

10 100 1000 10,000

\section{ELECTRODE SPACING,.AB/2, IN FEET}

Figure 28.--Schlumberger curve VES 27 


\section{ELECTRODE SPACING, AB/2, IN METERS}

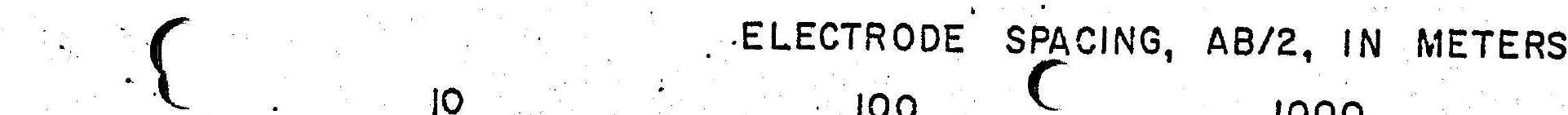

1000

$\sqrt{1+1+1}$

$31,3,1,2$ $100, \ldots$ 1000

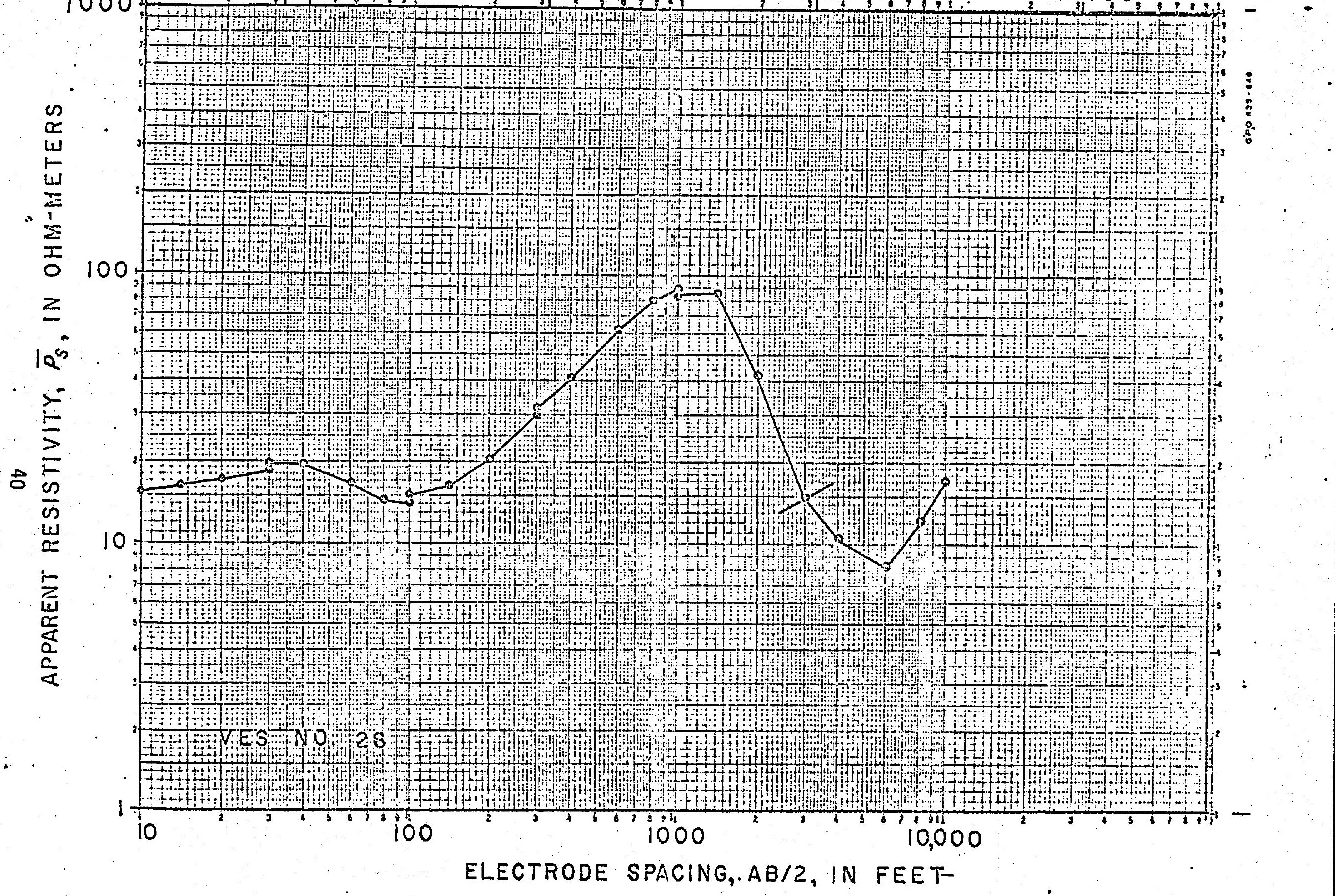

ELECTRODE SPACING,.AB/2, IN FEET-

Figure 29.--Sch7umberger curve VES. 28 


\section{ELECTRODE SPACING, AB/2, IN METERS}

1000

10

100

1000

10000

i

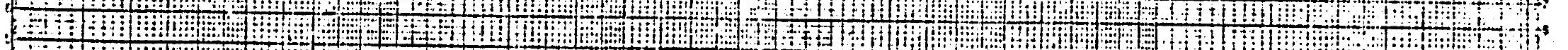
and

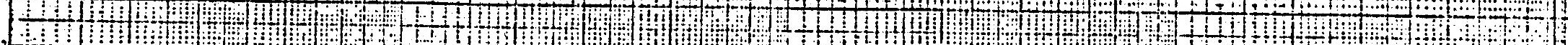

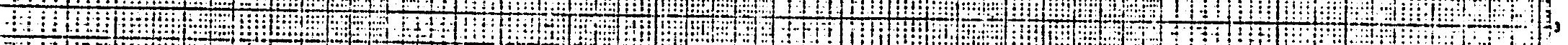

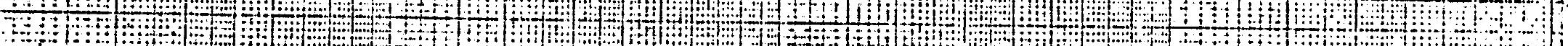

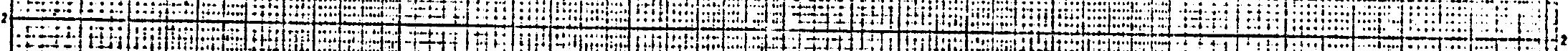

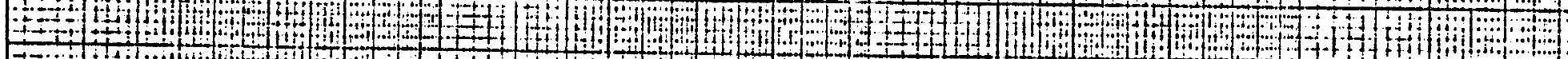

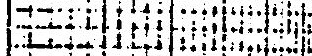

100

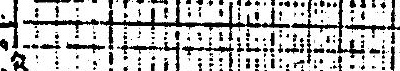

$1+\frac{1+4}{++1+1}$

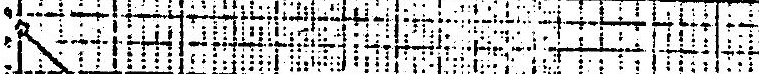

in:

(1)

a

a

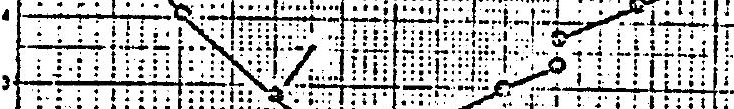

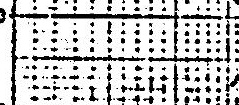

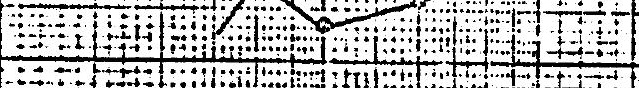

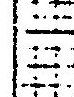

10 - 1 ihim

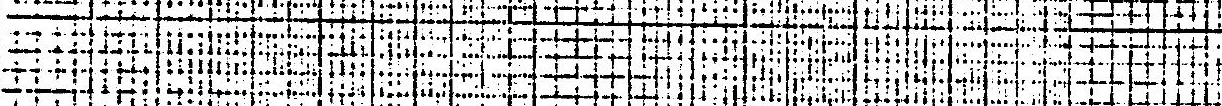

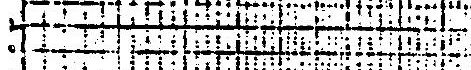

$17+17$

$1+$ Hallow

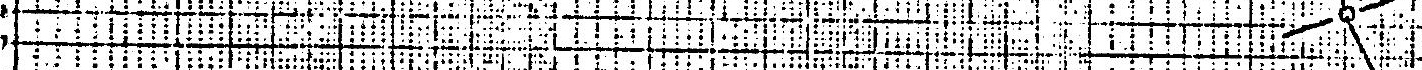

a

-

H I H

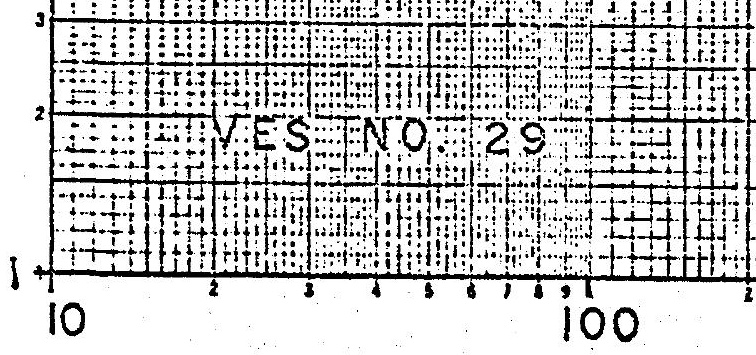

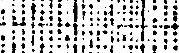



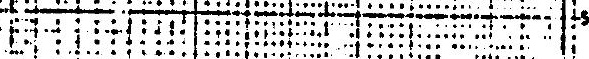

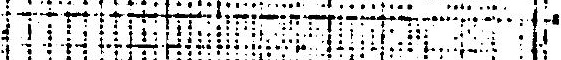

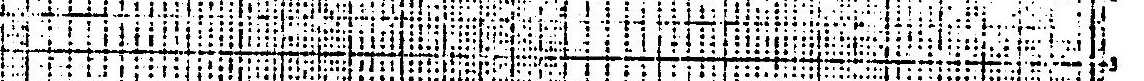

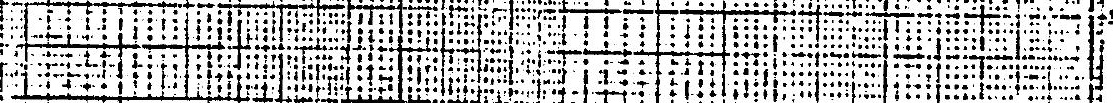
(1)


$17+$ Ift $1000 \quad 10,000$

ELECTRODE SPACING,AB/2, IN FEET-

Figure 30.--Schlumberger curve VES 29 


\section{ELECTRODE SPACING, AB/2, IN METERS}

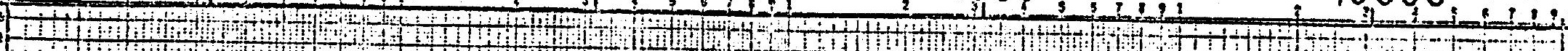

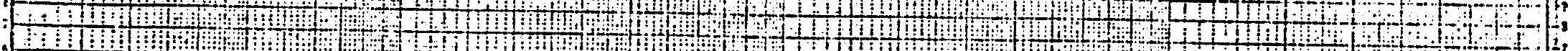

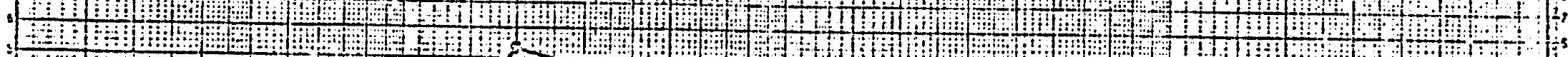

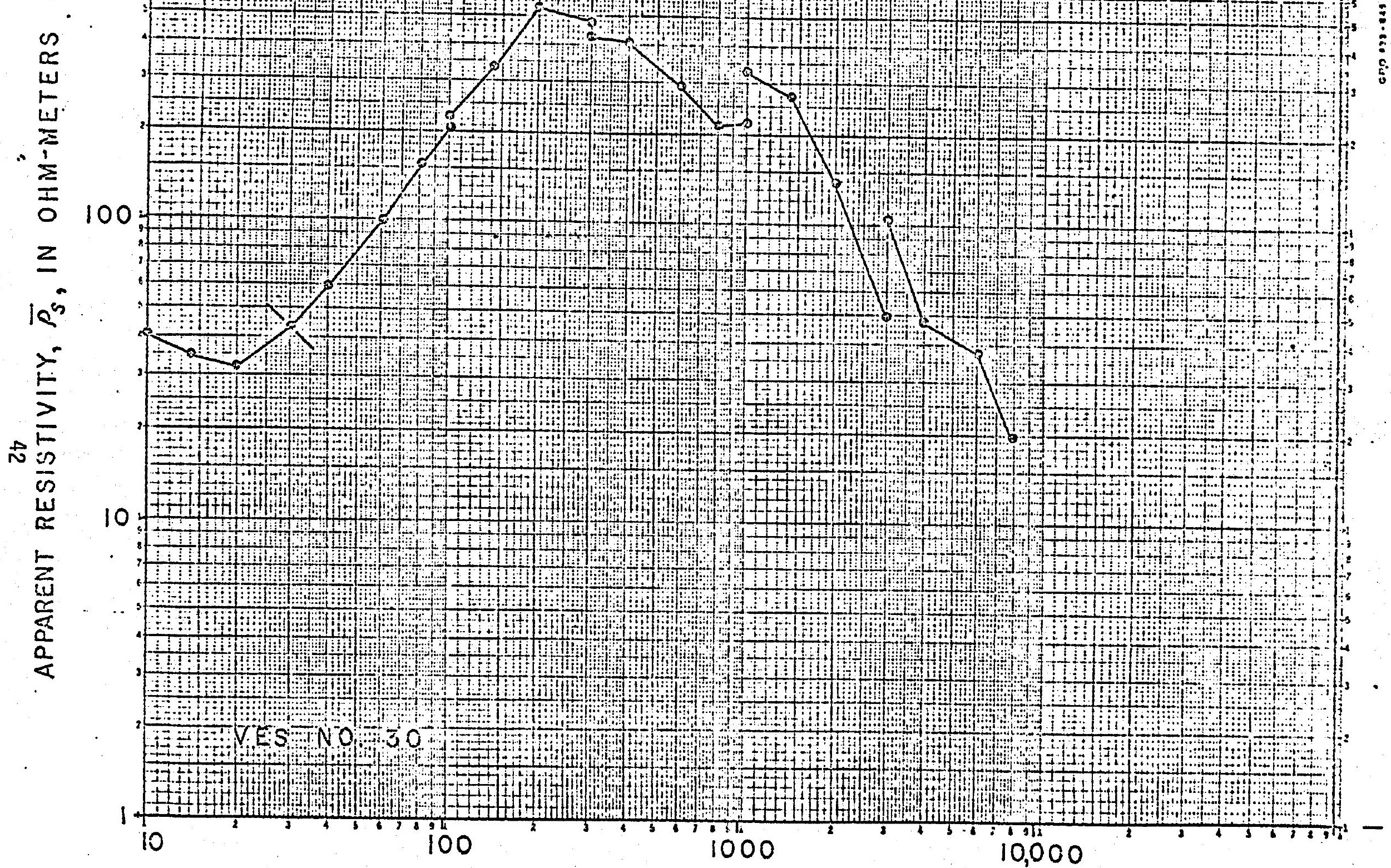

\section{ELECTRODE SPACING,.AB/2, IN FEET-}

Figure 31.--Schlumberger curve VES 30 


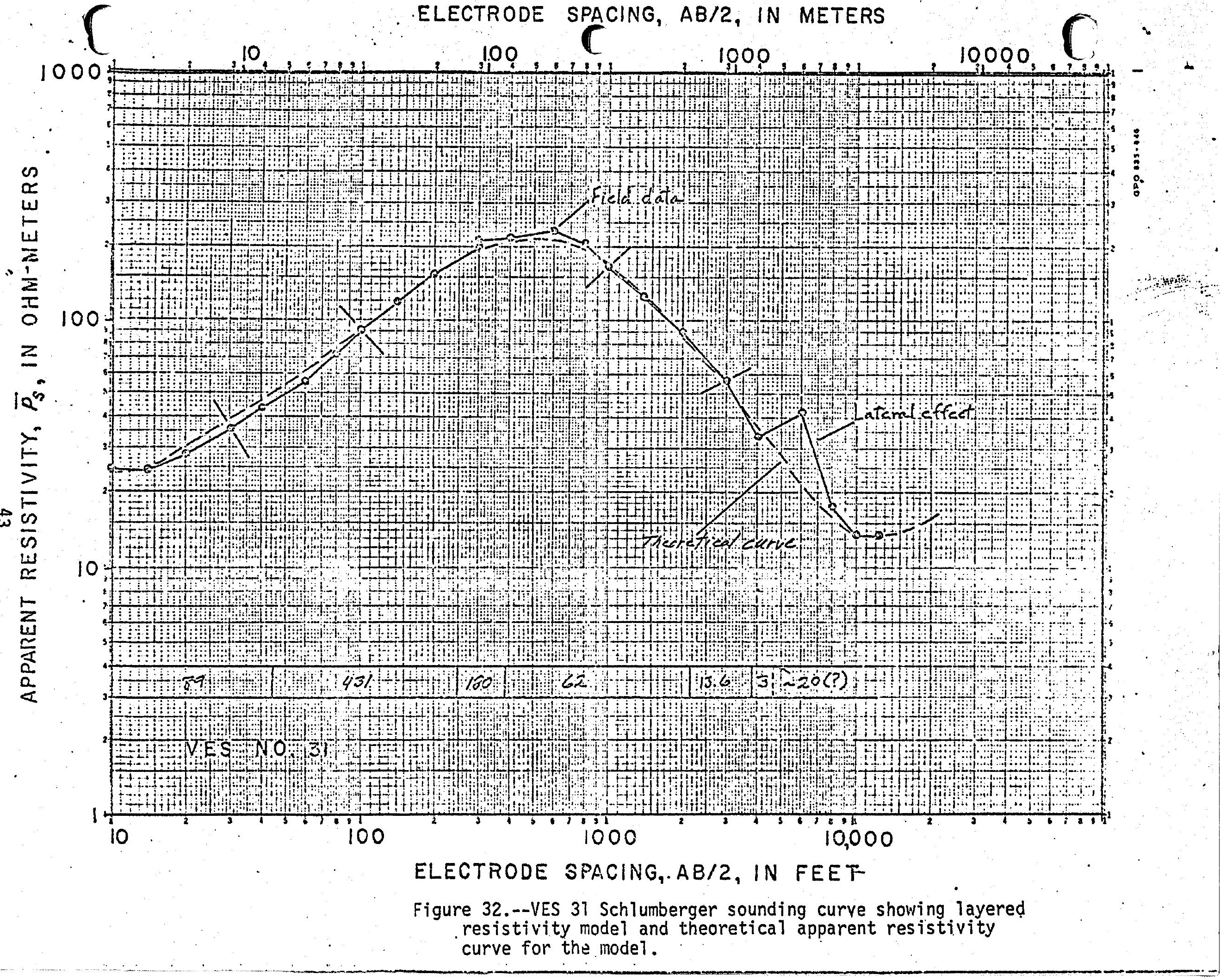




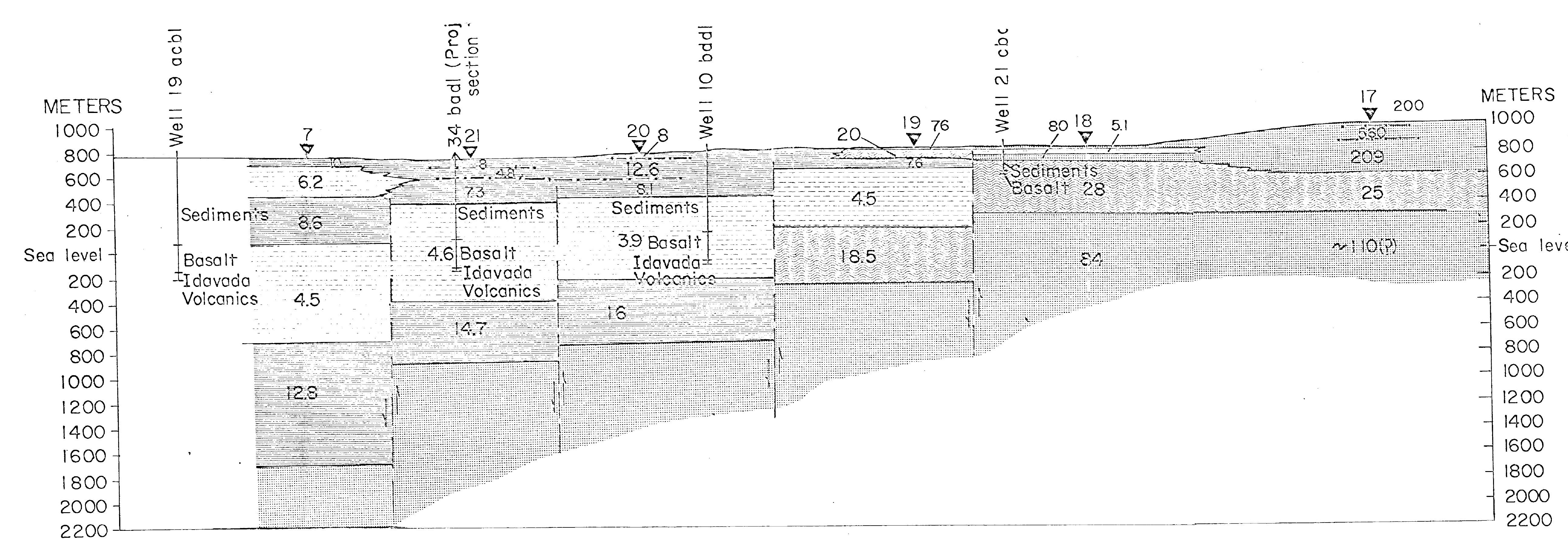

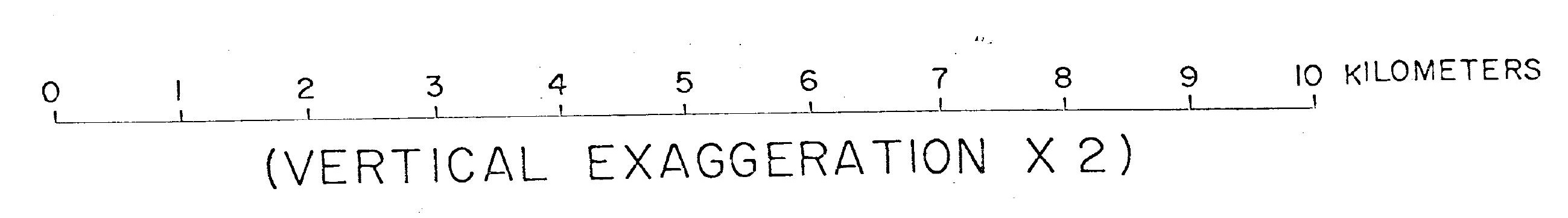

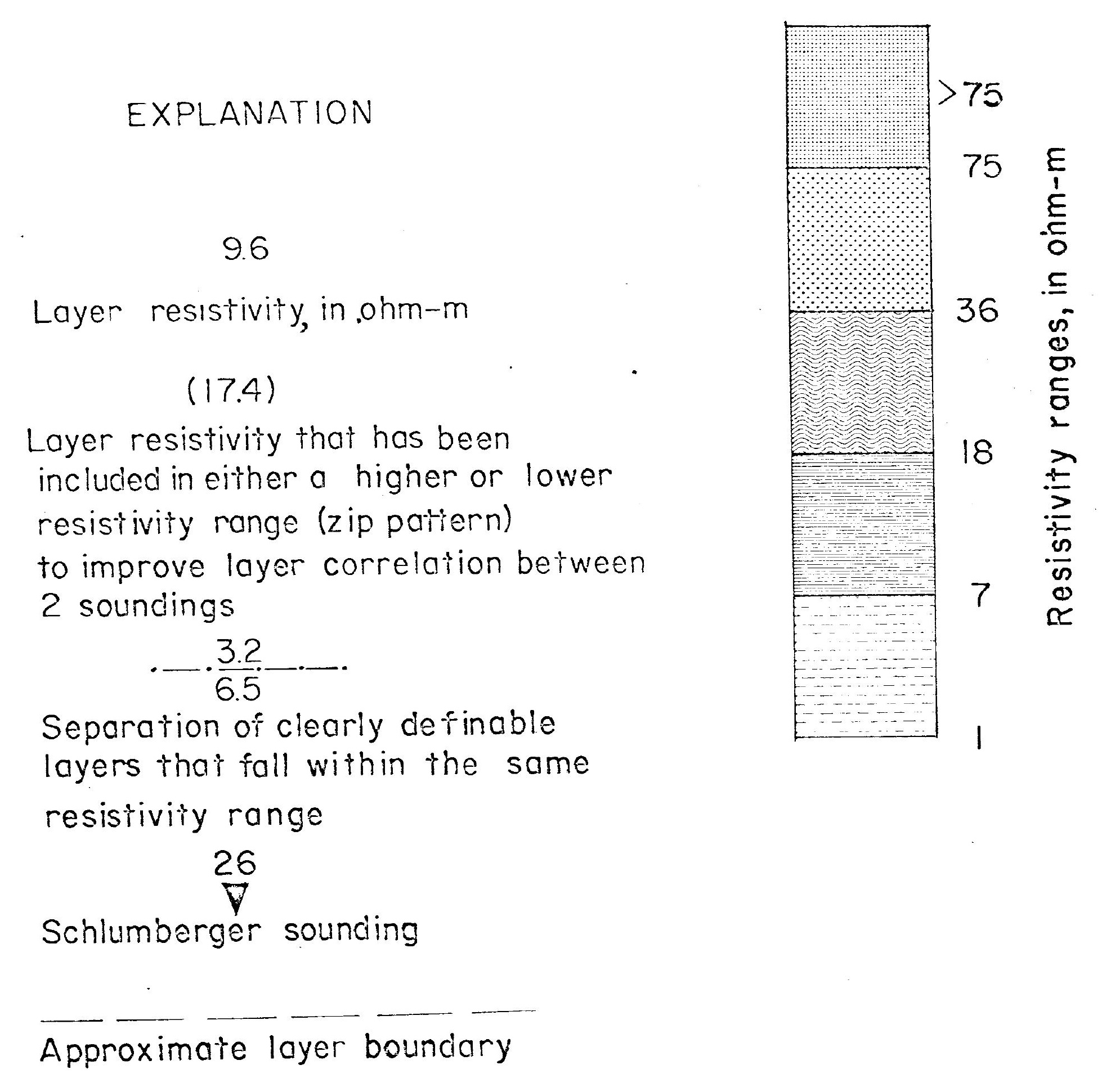

Plate 2. VES profiles $A A^{\prime}$ and $B B^{\prime}$, Bruneau-Grand View area, Idaho. 







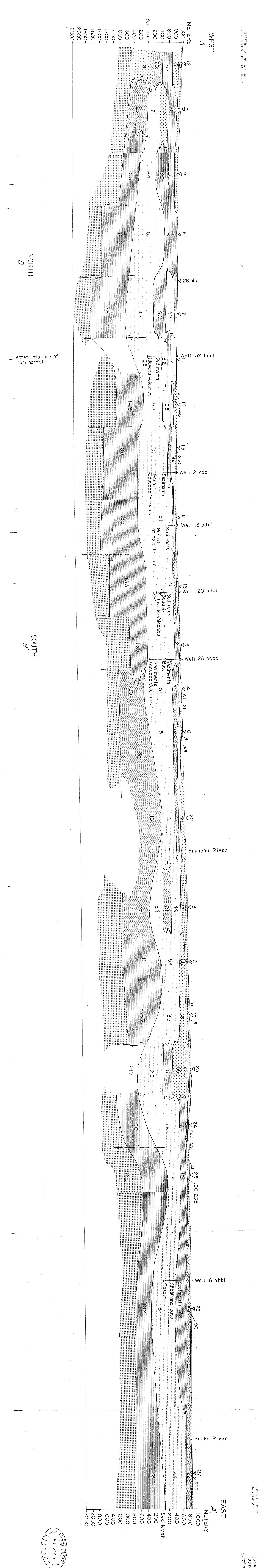




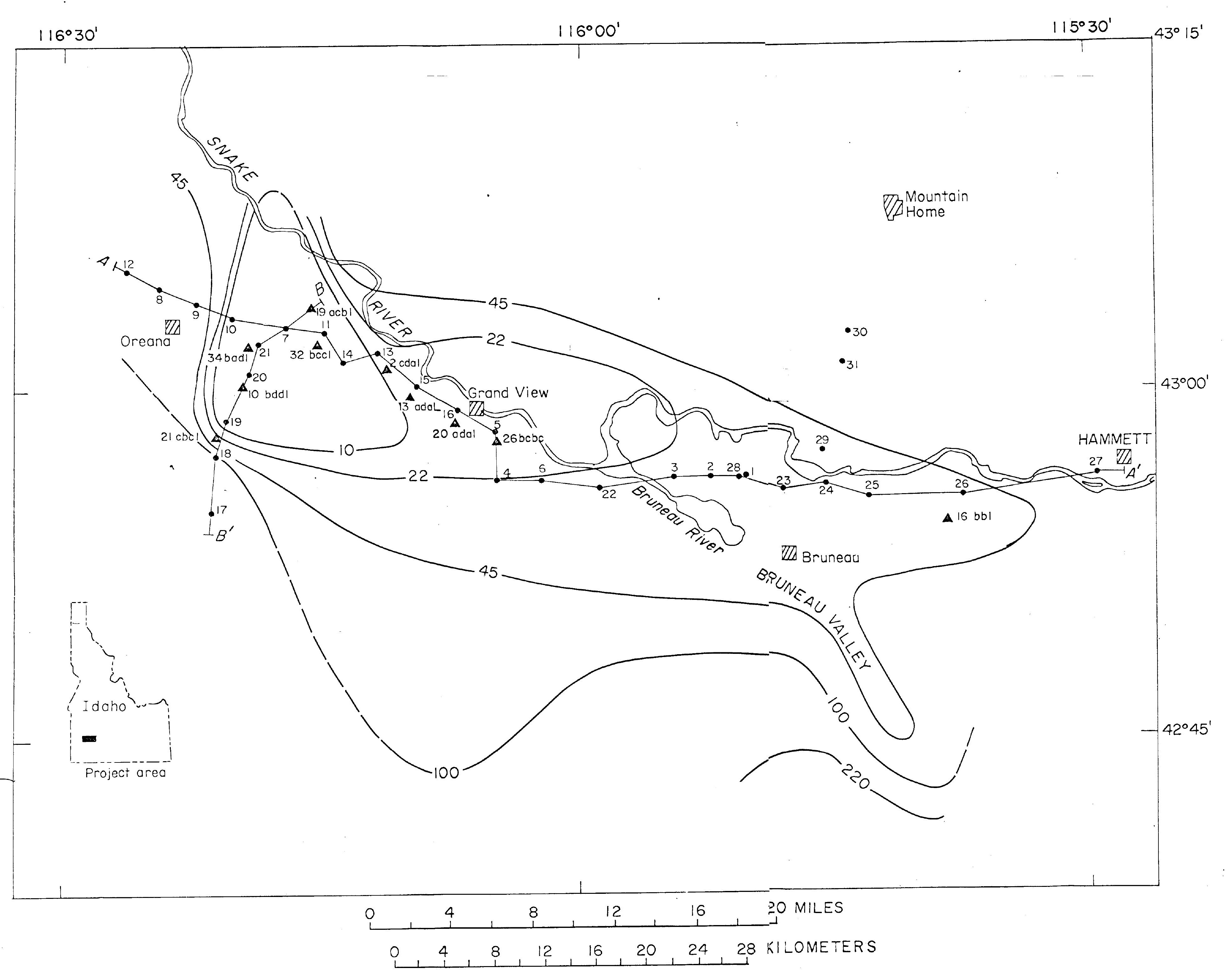

EXPLANATION

$\triangle 20$ odal

Woter well (no electric log dota)

.6

Schlumberger sounding

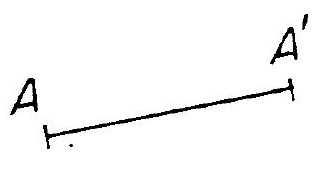

Resistivity cross-section $10^{0}$ -

Audio-magnetotelluric contour for $8 \mathrm{~Hz}$. Values in ohm-meters

Plate 1. Index map showing location of wells, soundings, geoelectric profiles $A-A^{\prime}$ and $B-B^{\prime}$, and AMT contours 